\title{
Mono- and Bis-Ortho-Chelated Lithium and Sodium Phenolates. Molecular Structures of the First Lithium Phenolate with a Stable, Trinuclear Structure and of a Tetranuclear Sodium Analog, $\left[\mathrm{MOC}_{6} \mathrm{H}_{2}\left(\mathrm{CH}_{2} \mathrm{NMe}_{2}\right)_{2}-2,6-\mathrm{Me}-4\right]_{x}(\mathrm{M}=\mathrm{Li}, x=3 ; \mathrm{M}=\mathrm{Na}, x=4)$
}

\author{
Paul A. van der Schaaf, ${ }^{\dagger}$ Johann T. B. H. Jastrzebski, ${ }^{\dagger}$ Marinus P. Hogerheide, ${ }^{\dagger}$ \\ Wilberth J. J. Smeets, ${ }^{\ddagger}$ Anthony L. Spek, ${ }^{\ddagger}$ Jaap Boersma, ${ }^{\dagger}$ and Gerard van Koten" ${ }^{*}$ \\ Department of Metal-Mediated Synthesis, Debye Institute, and Laboratory of Crystal and \\ Structural Chemistry, Bijvoet Center for Biomolecular Research, Utrecht University, \\ Padualaan 8, $3584 \mathrm{CH}$, The Netherlands
}

Received February 26, $1993^{\circ}$

\begin{abstract}
The lithium and sodium phenolates of 2-[(dimethylamino)methyl]phenol, 1a and 2a, 2-[(dimethylamino)methyl]4,6-dimethylphenol, $1 \mathrm{~b}$ and $2 \mathrm{~b}$, and 2,6-bis[(dimethylamino)methyl]-4-methylphenol, $1 \mathrm{c}$ and $2 \mathrm{c}$, respectively, have been synthesized. The structures of these complexes in solution were studied by variable-temperature ${ }^{1} \mathrm{H}$ and ${ }^{13} \mathrm{C}$ NMR spectroscopy and cryoscopic molecular weight measurements. The solid-state structures of complexes 1c and $2 \mathfrak{c}$ derived from 2,6-bis[(dimethylamino)methyl]-4-methylphenol, were determined by X-ray diffraction. The complexes containing only one ortho-chelating (dimethylamino)methyl group, i.e. 1a,b and $\mathbf{2 a , b}$, are soluble in weakly polar solvents, like tetrahydrofuran. Complexes $1 \mathrm{a}$ and $1 \mathrm{~b}$ are tetramers in benzene. These tetramers occur in solution in two isomeric forms, i.e. as aggregates with $D_{2}$ and $S_{4}$ symmetry. The lithium "pincer-phenolate" containing two ortho-chelating (dimethylamino)methyl groups (1c) is a trimer in apolar solvents as well as in the solid-state. It is the first example of a phenolate complex with a stable, trinuclear structure. In contrast, the sodium analog $(2 c)$ is a dimer in solution and crystallizes as a tetramer with a cubic-like $\mathrm{Na}_{4} \mathrm{O}_{4}$ core. Crystals of $\mathrm{Li}_{3} \mathrm{C}_{39} \mathrm{H}_{63} \mathrm{~N}_{6} \mathrm{O}_{3}$, $1 \mathrm{c}$, are monoclinic, space group $P 2_{1} / n$, with unit cell dimensions $a=42.381(5) \AA, b=8.8417(11) \AA, c=11.1802(10)$ $\AA, \beta=90.539(8)^{\circ}$, and $Z=4$. The structure was refined to $R=0.068$ for 4106 reflections and 610 parameters. The trimeric structure contains a $\mathrm{Li}_{3} \mathrm{O}_{3}$-ring which is almost perfectly planar (within $0.05 \AA$ ), and very short $\mathrm{Li}-\mathrm{O}$ and $\mathrm{C}-\mathrm{O}$ bond lengths (averages of $1.865(9)$ and 1.317(6) $\AA$, respectively). As a result of intramolecular amine coordination 1c is a "propeller-like" molecule with screw-type chirality. Crystals of $\mathrm{Na}_{4} \mathrm{C}_{52} \mathrm{H}_{84} \mathrm{~N}_{8} \mathrm{O}_{4} \cdot \mathrm{C}_{6} \mathrm{H}_{6}, 2 \mathrm{c}$, are monoclinic, space group $P 2 / c$, with $a=16.021(2) \AA, b=10.275(1) \AA, c=24.190(2) \AA, \beta=130.35(1)^{\circ}, Z=2$, and final $R=0.064$ for 3476 reflections and 400 parameters. This tetramer consists of a double dimer in which the $\mathrm{NMe}_{2}$ groups of one dimer do exclusively coordinate to the sodium atoms of the same dimer.
\end{abstract}

\section{Introduction}

Alkoxide and phenoxide ligands are often used as spectator ligands in early transition metal chemistry. 1,2 Like monoanionic carbon ligands, RO- ligands may occupy either terminal or bridging positions. Bulky alkoxide ligands can be selected to favor specific coordination numbers and geometries in much the same way as bulky phosphines or cyclopentadienyls are used. As a result of their uninegative charge and $\pi$-donating properties, alkoxide ligands are particularly suited to stabilize early transition metals in their mid-to-high oxidation states.

Our interest in this field is the synthesis of high-oxidationstate tungsten alkylidene complexes containing ligands in which a potentially intramolecularly coordinating tertiary amine is present. Recently, we reported the successful synthesis, characterization, and reactivity toward cyclic olefins of a tungsten(VI) alkylidene complex, containing an ortho-chelating aryl amine ligand, i.e. the 2-[(dimethylamino)methyl]phenyl anion, see Scheme I. ${ }^{3}$

* To whom correspondence should be addressed.

+ Debye Institute, Utrecht University.

1 Bijvoet Center for Biomolecular Research, Utrecht University.

- Abstract published in Advance ACS Abstracts, August 15, 1993.

(1) (a) Chisholm, M. H.; Rothwell, I. P. In Comprehensive Coordination Chemistry; Wilkinson, G., Ed.; Pergamon Press: Oxford, England, 1987; Vol. 2. (b) Buhro, W. E.; Chisholm, M. H. Adv. Organomet. Chem. 1987, 27, 311. (c) Rothwell, I. P. Acc. Chem. Res. 1988, 21, 153 and references cited therein.

(2) Bradley, D. C.; Mehrotra, R. C.; Gaur, D.P. Metal Alkoxides; Academic Press: London, 1978.

(3) van der Schaaf, P. A.; Smeets, W. J. J.; Spek, A. L.; van Koten, G. J Chem. Soc., Chem. Commun. 1992, 717.
Scheme I

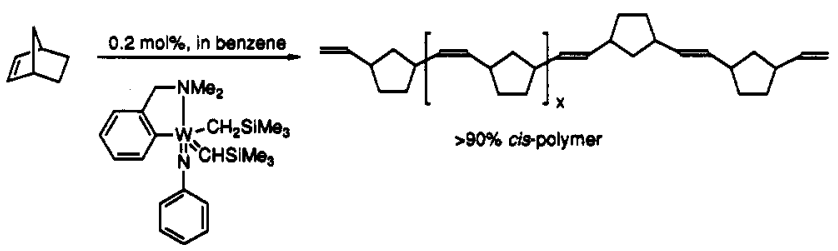

It has been well-established that the reactivity of metal alkylidene complexes can be tuned by the introduction of hard alkoxide ligands. ${ }^{4}$ Therefore, we have started a study in which the concept of tuning the reactivity of the alkylidene fragment by alkoxide ligands is combined with the use of intramolecularly coordinating tertiary amines. To this end we planned to use phenolates containing one or two ortho-chelating (dimethylamino)methyl groups, respectively (a, b, and c; see Figure 1). Lithium and sodium complexes of these ligands, $1 \mathrm{a}-\mathrm{c}$ and $\mathbf{2 a - c}$, respectively, were synthesized to be used as starting materials for the corresponding tungsten alkylidene complexes.

In the last decade Jackman et al. have reported on the structural features that affect the degree of association of lithium phenolates. $^{5-8}$ They showed that ortho-substituents in particular play an important role in the type of aggregates formed. The

(4) (a) Schrock, R. R.; Rocklage, S. M.; Fellman, J. D.; Ruprecht, G. A.; Messerle, L. W. J. Am. Chem. Soc. 1981, 103, 1440. (b) Schrock, R. R.; DePue, R. T.; Feldman, J.; Yap, K. B.; Yang, D. C.; Davies, W. M.; Park, L.; DiMare, M.; Schofield, M.; Anhaus, J.; Walborsky, E.; Evitt, E.; Krüger, C.; Betz, P. Organometallics 1990, 9, 2262.

(5) Jackman, L. M.; DeBrosse, C. W. J. Am. Chem. Soc. 1983, 105, 4177. 


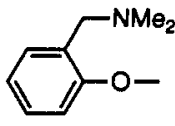

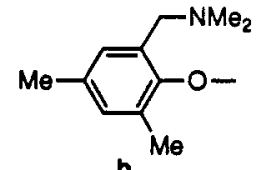

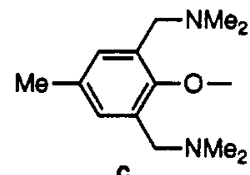

Figure 1. Studied phenolate ligands with one or two ortho-chelating $\mathrm{CH}_{2} \mathrm{NMe}_{2}$ groups.

Scheme II

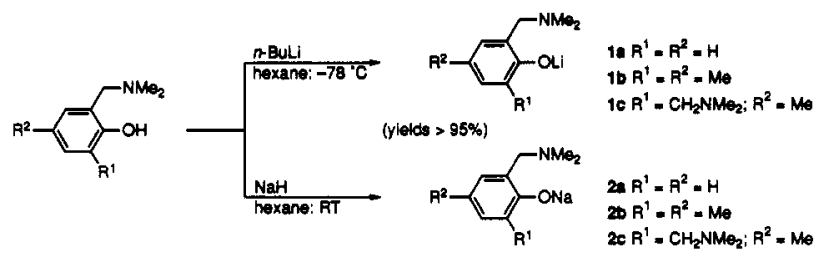

present study shows that not only are the lithium and sodium salts of ortho-chelating phenolates a, b, and $\mathbf{c}$ (see Figure 1) suitable starting materials for the synthesis of early-transition metal phenoxides but they exhibit themselves novel bonding features. ${ }^{9}$ This arises from the presence of both an anionic oxygen donor atom and of tertiary amine donors which are held in a stereochemically defined arrangement by the connecting arene ring. In the case of the bis-ortho-chelating "pincer-phenolate" (c), this has enabled the isolation of the first trinuclear lithium phenolate with a planar $\mathrm{Li}_{3} \mathrm{O}_{3}$ central core ${ }^{10}$ and of a tetrameric sodium phenolate with a cubane-like $\mathrm{Na}_{4} \mathrm{O}_{4}$ core.

Synthesis of the Phenols and Phenolates. 2-[(Dimethylamino)methyl]phenol (a) and 2-[(dimethylamino)methyl]-4,6-dimethylphenol (b) were made by reacting phenol or 2,4-dimethylphenol with dimethylamine and formaldehyde in water. ${ }^{11}$ This wellknown procedure appeared to be inconvenient for the synthesis of 2,6-bis[(dimethylamino)methyl]phenol, which was obtained in an unacceptable low yield, and which was often contaminated with 2,4,6-tris [(dimethylamino)methyl]phenol. However, its $p$-methyl derivative (c) was made quantitatively from 4-methylphenol and an excess of dimethylamine and formaldehyde.

The lithium phenolates $1 \mathrm{a}-\mathrm{c}$ were obtained quantitatively from the reaction of the respective phenols with $n$-BuLi in hexane at $-78{ }^{\circ} \mathrm{C}$. The sodium phenolates $2 a-c$ were obtained by the reaction of these phenols with sodium hydride in hexane at ambient temperature; see Scheme II.

Complexes of the Mono-Ortho-Chelating Phenolate Anion. The lithium phenolates $1 \mathbf{a}, \mathbf{b}$, and sodium phenolates $2 \mathbf{a}, \mathbf{b}$ are white, moisture-sensitive solids. These phenolates are very soluble in weakly polar solvents, such as THF and are very soluble without protonation in stronger polar, protic solvents, such as methanol. Selected NMR data are listed in Table I.

The lithium phenolates $1 \mathrm{a}, \mathrm{b}$ are soluble in benzene $(1 \mathrm{~b}$ is even slightly soluble in hexane), and molecular weights could therefore be determined by means of cryoscopy in benzene. Unfortunately, the sodium phenolates $2 \mathbf{a}, \mathbf{b}$ are completely insoluble in apolar solvents. It appeared that both $1 \mathrm{a}$ and $1 \mathrm{~b}$ exist as concentrationindependent tetramers in benzene; see Table II. Cryoscopic measurements on the lithium and sodium phenolates in THF

(6) Jackman, L. M.; Scarmoutzos, L. M. J. Am. Chem. Soc. 1987, 109, 5348.

(7) Jackman, L. M.; Smith, B. D. J. Am. Chem. Soc. 1988, 110, 3829

(8) Jackman, L. M.; Chen, X. J. Am. Chem. Soc. 1992, 114, 403.

(9) Recently, we already demonstrated the interesting properties of the "pincer-phenolate" ligand containing two ortho-chelating tertiary amine substituents with the synthesis and molecular structure in the solid-state of the copper phenolate $\mathrm{Cu}_{2}(\mu-\mathrm{Br})\left[\mu-\mathrm{OC}_{6} \mathrm{H}_{3}\left(\mathrm{CH}_{2} \mathrm{NMe}_{2}\right)_{2}-2,6\right]$ $\left[\mathrm{P}(\mathrm{OMe})_{3}\right]_{2}$ : Wehman, E.; van Koten, G.; Knotter, D. M.; Erkamp, C J. M.; Mali, A. N. S.; Stam, C. H. Recl. Trav. Chim. Pays-Bas 1987 106,370 .

(10) van der Schaaf, P. A.; Hogerheide, M. P.; Grove, D. M.; Spek, A. L.; van Koten, G. J. Chem. Soc., Chem. Commun. 1992, 1703.

(11) (a) Décombe, J. C.R. Seances Acad. Sci. 1933, 196, 866. (b) Bayer \& Co., Deutsches Reichspatent No. 89979 and 92309; Friedländers Fortschr. Teerfarbenfabr. 1985, 4, 103 were hampered by the absence of a sharp melting point of the gelatinized THF solutions, even at low phenolate concentrations.

Variable-temperature ${ }^{1} \mathrm{H}$ and ${ }^{13} \mathrm{C}$ NMR measurements of $1 \mathrm{a}$ in THF- $d_{8}$ showed one resonance pattern at ambient temperature. However, at $-60^{\circ} \mathrm{C}$ two patterns are observed, which indicate the presence of an equilibrium between two different aggregates of 1 a (tentatively assigned as A and B). Furthermore, the A to $B$ molar ratio strongly depends on the concentration (10:1 at 44.1 $\mathrm{mg} / \mathrm{mL}$ and 5:1 at $6.2 \mathrm{mg} / \mathrm{mL}$ THF- $d_{8}$ ). The phenolates $1 \mathrm{~b}$ and 2a,b show a similar behavior in THF- $d_{8}$. Although the resonances for $2 a, b$ are very badly resolved at $-60^{\circ} \mathrm{C}$, the tendency to split up in two sets of resonances is still visible.

The ${ }^{1} \mathrm{H}$ NMR spectrum of $1 \mathrm{a}$ in toluene- $d_{8}$ also shows two species, now in a molar ratio of approximately $1: 3$, which cryoscopy shows to be tetramers. The molar ratio of both species is concentration independent, but strongly depends on the temperature. The $\mathrm{CH}_{2} \mathrm{~N}$ hydrogens of the major component form an $\mathrm{AB}$ pattern while the $\mathrm{NMe}_{2}$ methyl groups appear as two distinct resonances. The minor component, however, gives broad signals. Addition of a few equivalents of THF to this toluene solution of 1a has a considerable effect on the spectrum: the sharp $\mathrm{AB}$ pattern for the $\mathrm{CH}_{2} \mathrm{~N}$ hydrogens and the anisochronous signals for the NMe groups of the major isomer disappear, whereas the resonances for the minor isomer remain unchanged. When this NMR experiment is carried out with $1 \mathrm{~b}$ in toluene- $d_{8}$, a similar result is obtained. The molar ratio of the observed isomers is now 1:4, with the minor isomer showing the $\mathrm{AB}$ pattern for the $\mathrm{CH}_{2} \mathrm{~N}$ hydrogens and two distinct signals for the $\mathrm{NMe}_{2}$ methyl groups, whereas the major isomer exhibits the broadened resonance pattern.

Complexes of the Bis-Ortho-Chelating Phenolate Anion. The lithium and sodium phenolates containing the "pincer-phenolate" ligand $\mathrm{c}, i . e$. $1 \mathrm{c}$ and $2 \mathrm{c}$, were obtained after recrystallization from hexane as white, moisture-sensitive solids. They are very soluble in apolar solvents like benzene and hexane. Molecular weight determinations by cryoscopy in benzene showed that the lithium "pincer-phenolate" $1 \mathrm{c}$ is a trimer in solution (concentration range $0.037-0.080 \mathrm{M}$ ). Interestingly, the sodium "pincer-phenolate" $2 \mathrm{c}$ appeared to be a dimer (concentration range $0.029-0.060 \mathrm{M}$ ). To determine the stereochemistry of both "pincer-phenolates" and their degree of association in the solid-state, $X$-ray diffraction studies on both complexes were carried out.

The crystal structure of 1c comprises the packing of four discrete, trimeric molecules in the unit cell. Each of these trimeric units possesses a pseudo-3-fold rotation axis. Two views of the molecular geometry of $\mathbf{1 c}$ are shown in Figure 2. The atomic coordinates for the molecule as well as the selected bond distances and angles, are collected in Tables III and IV, respectively.

Complex $1 \mathrm{c}$ is the first isolated and characterized trinuclear lithium phenolate. Since also in solution 1c has a trimeric structure, this molecular arrangement must be particularly stable. First, the $\mathrm{Li}-\mathrm{O}$ bond lengths (average $1.865(9) \AA$ ) are comparable with the shortest ever reported in related complexes, $i . e$. in dimeric lithium 2,6-di-tert-4-methylphenoxide, 3 (average $\mathrm{Li}-\mathrm{O}=1.858$ (11) $\AA$ ). ${ }^{12}$ Second, the $C_{i p s o}-O$ distances are very short and range from $1.301(6)$ to $1.326(6) \AA$, while corresponding distances in $3^{12}$ as well as in lithium enolates derived from ketones ${ }^{13}$ are close to $1.35 \AA$. Finally, $1 \mathrm{c}$ contains an almost perfectly planar $\mathrm{Li}_{3} \mathrm{O}_{3}$ six-membered central ring; see view $b$ in Figure 2 (maximum least-squares deviation is $0.05 \AA$ ). In this ring the $\mathrm{Li}-\mathrm{O}-\mathrm{Li}$ and $\mathrm{O}-\mathrm{Li}-\mathrm{O}$ angles are in the ranges $126.5-129.7$ and $110.1-112.4^{\circ}$, respectively, while $\Sigma^{\circ}$ is exactly $720.0^{\circ}$.

(12) Cetinkaya, B.; Gümrükçū, I.; Lappert, M. F.; Atwood, J. L.; Shakir, R. J. Am. Chem. Soc. 1980, 102, 2086

(13) (a) Amstutz, R.; Schweizer, W. B. Seebach, D.; Dunitz, J. D. Helv. Chim. Acta 1981, 64, 2617. (b) Seebach, D.; Amstutz, R.; Dunitz, J. D. Helv. Chim. Acta 1981, 64, 2622. (c) Seebach, D.; Amstutz, R.; Laube, T.; Schweizer, W. B.; Dunitz, J. D. J. Am. Chem. Soc. 1985, 107 5403. (d) Williard, P. G.; Carpenter, G. B. J. Am. Chem. Soc. 1986, 108, 462. (e) Seebach, D. Angew. Chem. 1988, 100, 1685. 
Table I. Relevant ${ }^{1} \mathrm{H}$ NMR Data for the Lithium and Sodium Phenolates, $1 \mathrm{a}-\mathrm{c}$ and $2 \mathrm{a}-\mathrm{c}^{a}$

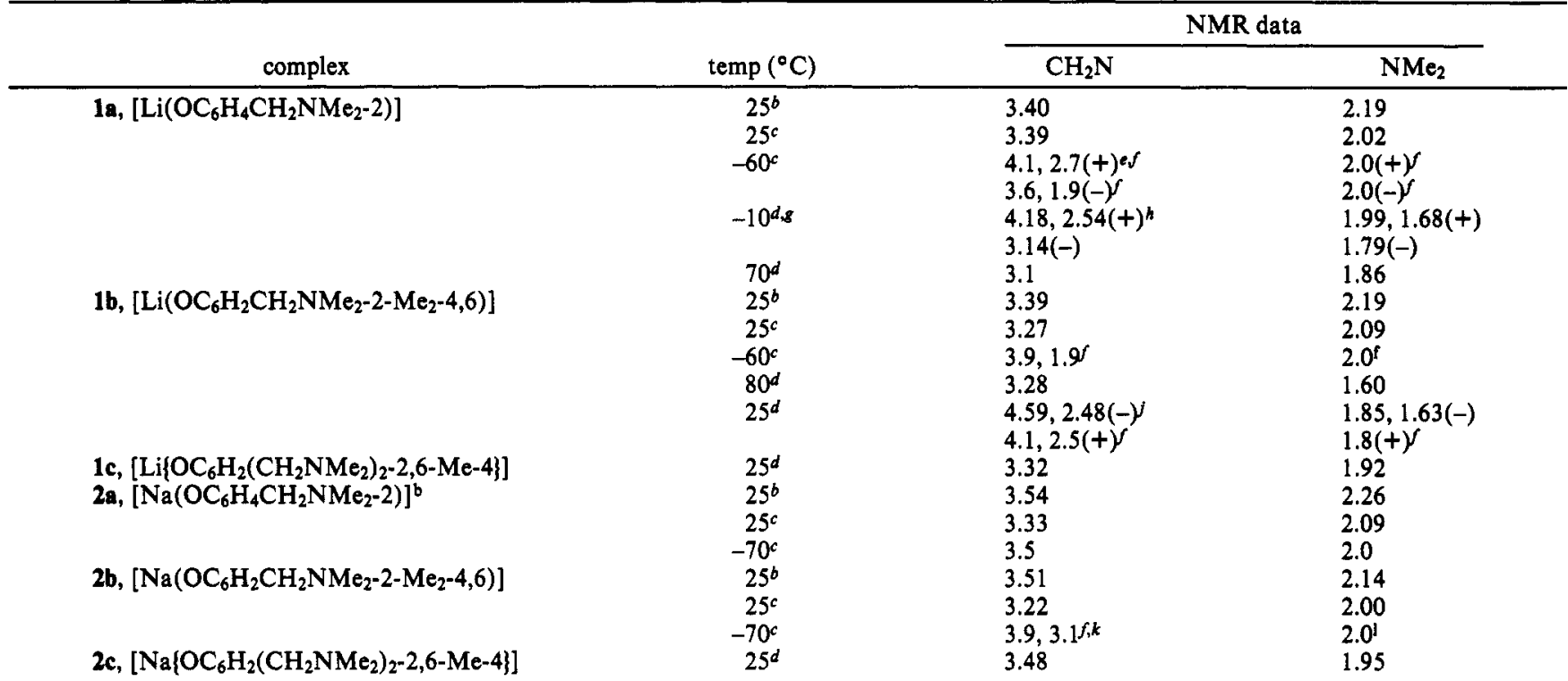

${ }^{a}$ Chemical shifts in $\delta$ are indirectly referenced to $\mathrm{SiMe}_{4}$ using solvent signals. ${ }^{b}$ In methanol $-d_{4}{ }^{c}{ }^{c}$ In THF- $d_{8}{ }^{d}$ In toluene- $d_{8} .{ }^{e}(-)=$ minor isomer; $(+)=$ major isomer. $f$ Poorly resolved. 8 Spectrum at $25^{\circ} \mathrm{C}$ badly resolved. $h 2 J_{\mathrm{H}, \mathrm{H}}=11.7 \mathrm{~Hz} . / 2 J_{\mathrm{H}, \mathrm{H}}=11.6 \mathrm{~Hz}$. ${ }^{k}$ Two left parts of AB pattern. 'Complex pattern.

Table II. Results of Cryoscopic Molecular Weight Determinations of the Lithium and Sodium Phenolates, $1 \mathrm{a}-\mathrm{c}$ and $2 \mathrm{a}-\mathrm{c}^{a}$

\begin{tabular}{clc}
\hline no. & \multicolumn{1}{c}{ compound } & $\begin{array}{c}\text { degree of } \\
\text { association }\end{array}$ \\
\hline 1a & {$\left[\mathrm{Li}\left(\mathrm{OC}_{6} \mathrm{H}_{4} \mathrm{CH}_{2} \mathrm{NMe}_{2}-2\right)\right]$} & 4.00 \\
1b & {$\left[\mathrm{Li}\left(\mathrm{OC}_{6} \mathrm{H}_{2} \mathrm{CH}_{2} \mathrm{NMe}_{2}-2-\mathrm{Me}_{2}-4,6\right)\right]$} & 3.90 \\
1c & {$\left[\mathrm{Li}\left(\mathrm{OC}_{6} \mathrm{H}_{2}\left(\mathrm{CH}_{2} \mathrm{NMe}_{2}\right)_{2}-2,6-\mathrm{Me}-4\right\}\right]$} & 2.95 \\
2a & {$\left[\mathrm{Na}\left(\mathrm{OC}_{6} \mathrm{H}_{4} \mathrm{CH}_{2} \mathrm{NMe}_{2}-2\right)\right]$} & $b$ \\
2b & {$\left[\mathrm{Na}\left(\mathrm{OC}_{6} \mathrm{H}_{2} \mathrm{CH}_{2} \mathrm{NMe}_{2}-2-\mathrm{Me}_{2}-4,6\right)\right]$} & $b$ \\
2c & {$\left[\mathrm{Na}\left(\mathrm{OC}_{6} \mathrm{H}_{2}\left(\mathrm{CH}_{2} \mathrm{NMe}_{2}\right)_{2}-2,6-\mathrm{Me}-4\right\}\right]$} & 2.05
\end{tabular}

- Measurements were carried out in benzene at two concentrations (see Experimental Section). ${ }^{b}$ Complexes are insoluble in benzene.

Adjacent lithium atoms are $\mathrm{N}$-coordinated by different $\mathrm{CH}_{2}$ $\mathrm{NMe}_{2}$ substituents of their mutually $\mathrm{O}$-bridging phenolate ligand. The orientation of these ligands with respect to the $\mathrm{Li}_{3} \mathrm{O}_{3}$ ring results in a "propeller-like" molecule with a screw-type chirality. ${ }^{14}$ In these molecules each of the six equivalent $\mathrm{CH}_{2} \mathrm{NMe}_{2}$ substituents has inequivalent $\mathrm{CH}_{2} \mathrm{~N}$ hydrogen atoms and $\mathrm{NMe}_{2}$ methyl groups. The diastereotopicity of these $\mathrm{CH}_{2} \mathrm{~N}$ hydrogens and $\mathrm{NMe}_{2}$ methyl groups is also reflected in the ${ }^{1} \mathrm{H}$ NMR spectrum of $1 \mathrm{c}$ in toluene- $d_{8}$ at $-80^{\circ} \mathrm{C}$. However, when the temperature is raised to $-68{ }^{\circ} \mathrm{C}$ the signals of the $\mathrm{NMe}_{2}$ methyl groups coalesce, indicating that a $\mathrm{Li}-\mathrm{N}$ dissociation/association process is active ( $\Delta G^{*}=40.1 \mathrm{~kJ} \mathrm{~mol}^{-1}$ ), but the $\mathrm{CH}_{2} \mathrm{~N}$ hydrogens remain diastereotopic; see Figure 3. When the temperature is raised further to $-10^{\circ} \mathrm{C}$ these signals also coalesce, indicating that a fast rotation around the $C_{i p s o}-O$ bond occurs $\left(\Delta G^{*}=48.7\right.$ $\mathrm{kJ} \mathrm{mol}{ }^{-1}$ ), and as a consequence the six $\mathrm{CH}_{2} \mathrm{NMe}_{2}$ substituents are completely equivalent; see Figure 3.

In $2 \mathrm{c}$ the lithium atom is replaced by a sodium atom. As these two metals differ greatly with respect to their ionic radii $(0.68$ vs $0.97 \AA$ for lithium and sodium, respectively), ${ }^{15} \mathrm{a}$ change in the degree of association in solution could be anticipated and was found, i.e., from trimeric for $1 \mathrm{c}$ to dimeric for the sodium analog 2c. The solid-state structure of the latter was determined as well.

The crystal structure of $2 \mathrm{c}$ involves the packing of two discrete tetrameric molecules and two benzene solvate molecules in the unit cell. The tetrameric unit possesses a twofold rotation axis. The molecular geometry of $2 c$ is shown in Figure 4 . The atomic

(14) Both enantiomers are present in the crystal structure.

(15) Lide, D. R., Ed. Handbook for Chemistry and Physics, 72 nd ed.; C.R.C. Press: Boston, MA, 1992
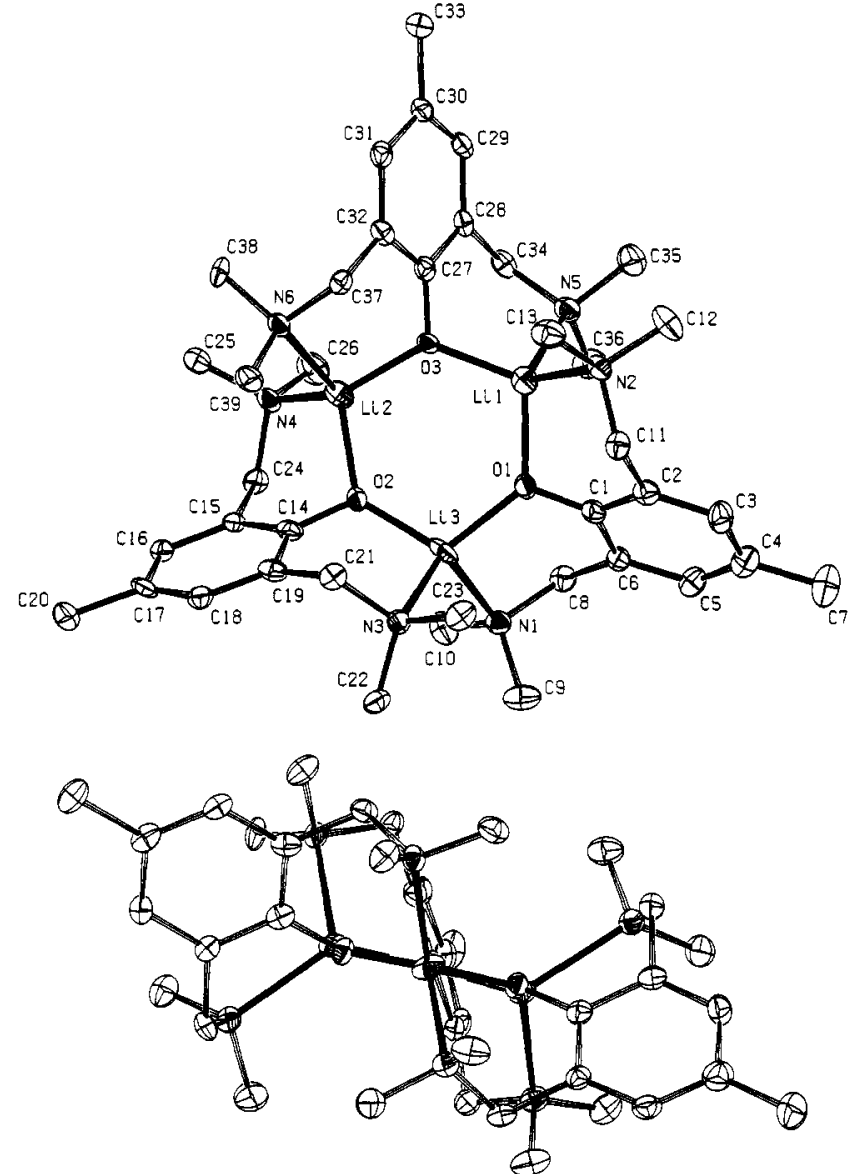

Figure 2. ORTEP drawings of the molecular structure of $\left[\mathrm{Li}\left\{\mathrm{OC}_{6} \mathrm{H}_{2} \mathrm{CCH}_{2}\right.\right.$ $\left.\left.\left.\mathrm{NMe}_{2}\right)_{2}-2,6-\mathrm{Me}-4\right\}\right]_{3}$ (1c) (with $50 \%$ probability ellipsoids), viewed perpendicular to (a, top) and along ( $b$, bottom) the $\mathrm{Li}_{3} \mathrm{O}_{3}$ plane. The $\mathrm{H}$ atoms are omitted for clarity.

coordinates for the molecule as well as the selected bond distances and angles, are listed in Tables V and VI, respectively.

Compound $2 \mathrm{c}$ is the first example of a tetrameric sodium phenolate with a cubane-like $\mathrm{Na}_{4} \mathrm{O}_{4}$ core. The sodium atoms are five-coordinate: they are bonded to three oxygen atoms in the $\mathrm{Na}_{4} \mathrm{O}_{4}$ core, and to two intramolecularly coordinating tertiary amino groups originating from two phenolate ligands. In an earlier 
Table III. Fractional Coordinates and Equivalent Isotropic Thermal Parameters for $\left[\mathrm{LiOC}_{6} \mathrm{H}_{2}\left(\mathrm{CH}_{2} \mathrm{NMe}_{2}\right)_{2}-2,6-\mathrm{Me}-4\right]_{3}$ (1c)

\begin{tabular}{|c|c|c|c|c|}
\hline atom & $x$ & $y$ & $z$ & $U_{\text {eq }}\left(\AA^{2}\right)$ \\
\hline $\mathrm{Li}(1)$ & $0.11435(19)$ & $0.7628(9)$ & $0.3491(7)$ & $0.023(3)$ \\
\hline $\operatorname{Li}(2)$ & $0.1671(2)$ & $0.8499(9)$ & $0.1380(7)$ & $0.024(3)$ \\
\hline $\operatorname{Li}(3)$ & $0.0894(2)$ & $0.8782(10)$ & $0.0783(7)$ & $0.026(3)$ \\
\hline$O(1)$ & $0.08301(7)$ & $0.8188(3)$ & $0.2378(3)$ & $0.0189(11)$ \\
\hline$O(2)$ & $0.13123(7)$ & $0.8832(4)$ & $0.0402(3)$ & $0.0189(11)$ \\
\hline$O(3)$ & $0.15492(7)$ & $0.7923(3)$ & $0.2894(3)$ & $0.0183(10)$ \\
\hline $\mathrm{N}(1)$ & $0.05500(9)$ & $0.7229(4)$ & $0.0039(3)$ & $0.0204(12)$ \\
\hline $\mathrm{N}(2)$ & $0.09202(9)$ & $0.8940(5)$ & $0.4993(3)$ & $0.0207(14)$ \\
\hline$N(3)$ & $0.07915(9)$ & $1.1120(4)$ & $0.0148(3)$ & $0.0190(12)$ \\
\hline $\mathrm{N}(4)$ & $0.19022(9)$ & $0.7078(4)$ & $-0.0011(3)$ & $0.0197(12)$ \\
\hline $\mathrm{N}(5)$ & $0.12550(9)$ & $0.5297(5)$ & $0.4110(3)$ & $0.0217(16)$ \\
\hline$N(6)$ & $0.20232(9)$ & $1.0290(4)$ & $0.2124(3)$ & $0.0183(12)$ \\
\hline$C(1)$ & $0.05521(11)$ & $0.7804(5)$ & $0.2756(4)$ & $0.0190(17)$ \\
\hline$C(2)$ & $0.04291(11)$ & $0.8412(5)$ & $0.3836(4)$ & $0.0213(17)$ \\
\hline$C(3)$ & $0.01365(12)$ & $0.7930(6)$ & $0.4259(5)$ & $0.0266(17)$ \\
\hline$C(4)$ & $-0.00465(12)$ & $0.6859(6)$ & $0.3642(5)$ & $0.0297(17)$ \\
\hline$C(5)$ & $0.00700(12)$ & $0.6320(6)$ & $0.2577(5)$ & $0.0243(17)$ \\
\hline$C(6)$ & 0.03 & $0.6761(5)$ & 0.211 & $7(17)$ \\
\hline$C(7)$ & $-0.03591(12)$ & $0.6321(7)$ & $0.4135(5)$ & $3(2)$ \\
\hline $\mathrm{C}(8)$ & $0.04909(12)$ & $0.6097(6)$ & $0.0988(5)$ & $0.0214(17)$ \\
\hline$C(9)$ & $0.02499(12)$ & $0.7810(6)$ & $-0.0413(5)$ & $0.0318(17)$ \\
\hline$C(10)$ & $0.07195(12)$ & $0.6482(6)$ & -0.0 & $6(19)$ \\
\hline$C(11)$ & $0.06293(11)$ & $0.9567(5)$ & $60(4)$ & $30(17)$ \\
\hline$C(12)$ & $0.08458(14)$ & $0.8228(6)$ & $136(4)$ & $33(19)$ \\
\hline$C(13)$ & $0.11539(14)$ & $1.0135(7)$ & $0.5202(5)$ & $0.031(2)$ \\
\hline$C(14)$ & $0.14194(11)$ & $0.9600(6)$ & -0.0 & (17) \\
\hline$C(15)$ & $00(11)$ & $0.8937(6)$ & $-0.1-1$ & $70(17)$ \\
\hline$C(16)$ & $0.17589(11)$ & $0.9767(6)$ & $-0.2259(4)$ & $0.0193(17)$ \\
\hline$C(17)$ & $18(12)$ & $1.1281(6)$ & -0.2 & $0.0224(17)$ \\
\hline$C(18)$ & 0.14 & $1.1936(6)$ & $-0.1-1-1$ & $0(17)$ \\
\hline$C(19)$ & $0.13294(11)$ & $1.1131(6)$ & $-0.0711(4)$ & $1(17)$ \\
\hline$C(20)$ & $0.18301(15)$ & $1.2163(7)$ & $-0.3425(5)$ & $0.0307(19)$ \\
\hline$C(21)$ & $99(12)$ & $1.1825(6)$ & $0.0164(5)$ & $0.0207(17)$ \\
\hline$C(22)$ & 0.06 & $1.1487(7)$ & -0.0 & $50(19)$ \\
\hline$C(23)$ & $0.06034(13)$ & $1.1668(7)$ & & 70(17) \\
\hline$C(24)$ & $0.17075(12)$ & $0.7282(6)$ & $-0.1112(4)$ & $0.0203(17)$ \\
\hline$C(25)$ & 0.223 & $0.7434(7)$ & -0.0 & $70(17)$ \\
\hline$C(26)$ & $0.18827(14)$ & $0.5485(6)$ & $0.0376(5)$ & $30(19)$ \\
\hline$C(27)$ & $0.17738(11)$ & $0.7686(5)$ & $0.3704(4)$ & $76(17)$ \\
\hline$C(28)$ & $0.18070(11)$ & $0.6259(6)$ & & $0.0183(17)$ \\
\hline$C(29)$ & 0.203 & & & $03(17)$ \\
\hline$C(30)$ & $0.22423(11)$ & $0.7181(6)$ & $0.5470(4)$ & $0.0210(17)$ \\
\hline$C(31)$ & $0.22169(12)$ & $0.8575(6)$ & $0.4894(4)$ & $0.0206(17)$ \\
\hline$C(32)$ & $0.19871(11)$ & $0.8842(6)$ & $0.4023(4)$ & $0.0196(17)$ \\
\hline$C(33)$ & & & & $0.0310(19)$ \\
\hline$C(34)$ & $0.15891(12)$ & $0.5017(6)$ & $0.3821(5)$ & $0.0220(17)$ \\
\hline$C(35)$ & $0.11984(15)$ & $0.4930(7)$ & $0.5378(5)$ & $0.031(2)$ \\
\hline$C(36)$ & $0.10486(13)$ & $0.4314(6)$ & $0.3378(5)$ & $0.033(2)$ \\
\hline & $0.19476(12)$ & & $0.3420(4)$ & $0.0193(17)$ \\
\hline$C(38)$ & & & & $0.0249(19)$ \\
\hline$C(39)$ & $0.19354(13)$ & $1.1744(7)$ & $0.1578(5)$ & $0.0280(17)$ \\
\hline
\end{tabular}

Table IV. Selected Geometrical Data for $\left[\mathrm{LiOC}_{6} \mathrm{H}_{2}\left(\mathrm{CH}_{2} \mathrm{NMe}_{2}\right)_{2}-2,6-\mathrm{Me}-4\right]_{3}$ (1c)

\begin{tabular}{lccc}
\multicolumn{4}{c}{ Bond Lengths $(\AA)$} \\
$\mathrm{Li}(1)-\mathrm{O}(1)$ & $1.878(9)$ & $\mathrm{Li}(1)-\mathrm{O}(3)$ & $1.869(9)$ \\
$\mathrm{Li}(2)-\mathrm{O}(3)$ & $1.846(9)$ & $\mathrm{Li}(2)-\mathrm{O}(2)$ & $1.887(9)$ \\
$\mathrm{Li}(3)-\mathrm{O}(2)$ & $1.828(9)$ & $\mathrm{Li}(3)-\mathrm{O}(1)$ & $1.881(9)$ \\
$\mathrm{Li}(1)-\mathrm{N}(2)$ & $2.256(9)$ & $\mathrm{Li}(1)-\mathrm{N}(5)$ & $2.223(9)$ \\
$\mathrm{Li}(2)-\mathrm{N}(4)$ & $2.233(9)$ & $\mathrm{Li}(2)-\mathrm{N}(6)$ & $2.325(9)$ \\
$\mathrm{Li}(3)-\mathrm{N}(1)$ & $2.163(9)$ & $\mathrm{Li}(3)-\mathrm{N}(3)$ & $2.227(9)$ \\
$\mathrm{O}(1)-\mathrm{C}(1)$ & $1.301(6)$ & $\mathrm{O}(2)-\mathrm{C}(14)$ & $1.326(6)$ \\
$\mathrm{O}(3)-\mathrm{C}(27)$ & $1.324(6)$ & & \\
\multicolumn{5}{c}{$\mathrm{B}$} \\
$\mathrm{O}(1)-\mathrm{Li}(1)-\mathrm{O}(3)$ & $112.0(4)$ & $\mathrm{Li}(1)-\mathrm{O}(1)-\mathrm{Li}(3)$ & $126.5(4)$ \\
$\mathrm{O}(2)-\mathrm{Li}(2)-\mathrm{O}(3)$ & $110.1(4)$ & $\mathrm{Li}(2)-\mathrm{O}(2)-\mathrm{Li}(3)$ & $129.7(4)$ \\
$\mathrm{O}(1)-\mathrm{Li}(3)-\mathrm{O}(2)$ & $112.1(4)$ & $\mathrm{Li}(1)-\mathrm{O}(3)-\mathrm{Li}(2)$ & $129.2(4)$
\end{tabular}

reported X-ray structure of the sodium salt of [1-(o-carboxymethoxyphenoxy)-2-( $\alpha$-hydroxyphenoxy)ethane] $4,{ }^{16}$ which also contains a cubane-like $\mathrm{Na}_{4} \mathrm{O}_{4}$ core, four oxygen atoms coordinate intramolecularly to two different, seven-coordinate sodium atoms. The $\mathrm{O}-\mathrm{Na}-\mathrm{O}$ angles of the $\mathrm{Na}_{4} \mathrm{O}_{4}$ core (ranging

(16) Hughes, D. L.; Wingfield, J. N. J. Chem. Soc., Chem. Commun. 1984, 408 .

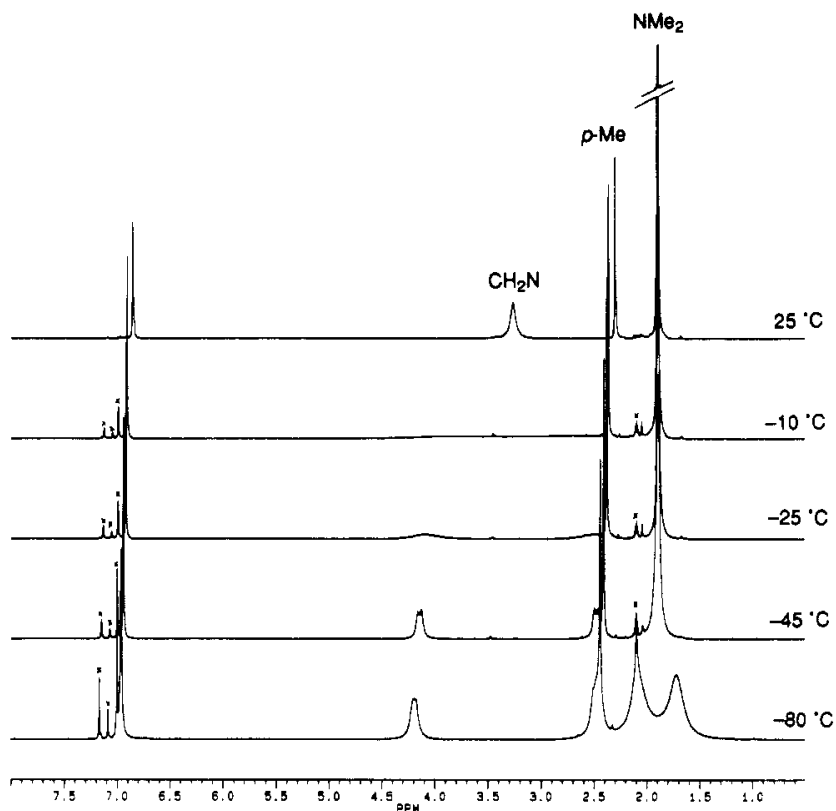

Figure 3. Variable-temperature NMR spectra of $\left[\mathrm{LiOC}_{6} \mathrm{H}_{2}\left(\mathrm{CH}_{2} \mathrm{NMe}_{2}\right)_{2-}\right.$ $2,6-\mathrm{Me}-4]_{3}$ (1c) (300 MHz in toluene- $\left.d_{8}\right)$ (*, residual solvent signals).

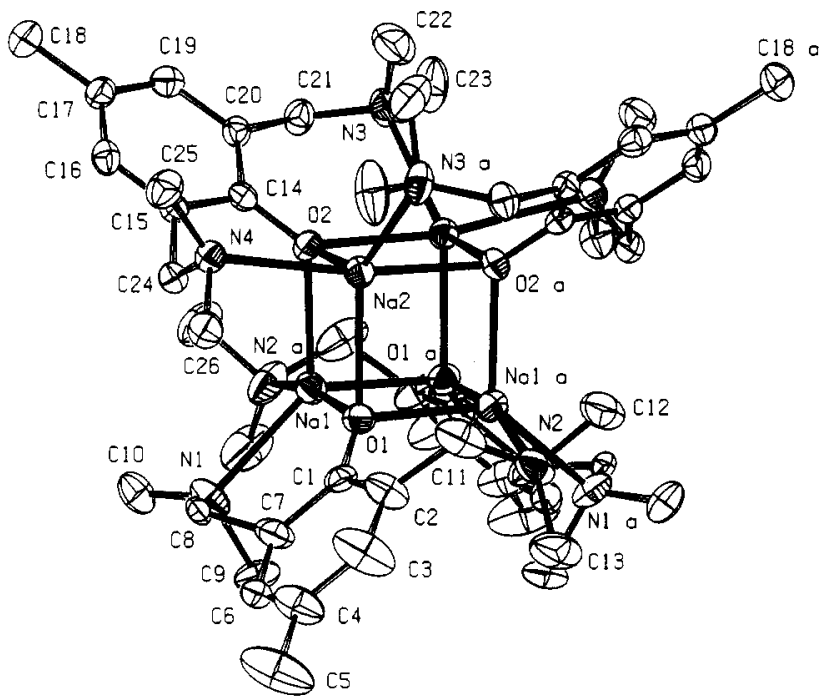

Figure 4. ORTEP drawing of the molecular structure of $\left[\mathrm{NaOC}_{6} \mathrm{H}_{2}\left(\mathrm{CH}_{2}\right.\right.$ $\left.\left.\mathrm{NMe}_{2}\right)_{2}-2,6-\mathrm{Me}-4\right]_{4} 2 \mathrm{c}$ (with $50 \%$ probability ellipsoids). The benzene solvate molecule and $\mathrm{H}$ atoms are omitted for clarity.

from $90.69(11)$ to $91.93(10)^{\circ}$ ) are slightly larger than $90^{\circ}$, and the $\mathrm{Na}-\mathrm{O}-\mathrm{Na}$ angles (ranging from 88.03(10) to $89.28(14)^{\circ}$ ) are correspondingly slightly smaller than $90^{\circ}$. The $\mathrm{Na}-\mathrm{O}$ distances (ranging from $2.325(4)$ to $2.417(2) \AA$ ) are close to those in $4^{16}$ and in the tetrameric sodium enolate of pinacolone, which also contains a cubane-like $\mathrm{Na}_{4} \mathrm{O}_{4}$ core. ${ }^{13 \mathrm{~d}}$ The $C_{\text {ipso }}-\mathrm{O}$ distances of 1.324(6) $\AA$ are normal for phenolates bonded to sodium. The tetrameric cluster can be seen as a double dimer in which the two sodium atoms of each dimer are bonded with two terdentate "pincer-phenolate" ligands; however, there is no significant lengthening of the "interdimeric" $\mathrm{Na}-\mathrm{O}$ bonds with respect to those within the dimeric unit.

The ${ }^{1} \mathrm{H}$ NMR spectrum of $2 \mathrm{c}$ in toluene- $d_{8}$ at room temperature shows equivalent $\mathrm{NMe}_{2}$ methyl groups and methylene hydrogens, indicating that, as in 1c (vide supra), a fast $\mathrm{Na}-\mathrm{N}$ dissociation/ association process of the $\mathrm{NMe}_{2}$ group and rotation of the aryl ring occurs on the NMR time scale. When this solution is cooled to $-5^{\circ} \mathrm{C}$, the signal for the $\mathrm{CH}_{2} \mathrm{~N}$ hydrogens starts to decoalesce. On further cooling to $-70^{\circ} \mathrm{C}$, a second species, most probably the tetrameric aggregate of $2 c$, begins to appear before the temperature is reached where the signal for the $\mathrm{NMe}_{2}$ groups starts to decoalesce. 
Table V. Fractional Coordinates and Equivalent Isotropic Thermal Parameters for $\left[\mathrm{NaOC}_{6} \mathrm{H}_{2}\left(\mathrm{CH}_{2} \mathrm{NMe}_{2}\right)_{2}-2,6-\mathrm{Me}-4\right]_{4} \cdot \mathrm{C}_{6} \mathrm{H}_{6}$ (2c)

\begin{tabular}{|c|c|c|c|c|}
\hline & $x$ & $y$ & $z$ & $U_{e q^{a}}\left(\AA^{2}\right)$ \\
\hline $\mathrm{Na}(1)$ & $0.09115(11)$ & $0.78692(13)$ & $0.33890(7)$ & $0.0288(4)$ \\
\hline $\mathrm{Na}(2)$ & $0.09711(11)$ & $1.01882(13)$ & $0.24660(7)$ & $0.0257(4)$ \\
\hline$O(1)$ & $0.09919(19)$ & $0.7836(2)$ & $0.24556(12)$ & $0.0302(8)$ \\
\hline$O(2)$ & $0.09470(18)$ & $1.0157(2)$ & $0.34224(11)$ & $0.0239(7)$ \\
\hline $\mathbf{N}(1)$ & $0.2457(3)$ & $0.6305(3)$ & $0.39386(18)$ & $0.0380(12)$ \\
\hline$N(2)$ & $-0.0671(3)$ & $0.7413(3)$ & $0.06367(16)$ & $0.0472(11)$ \\
\hline $\mathrm{N}(3)$ & $-0.0667(2)$ & $1.1913(3)$ & $0.33577(15)$ & $0.0352(10)$ \\
\hline$N(4)$ & $0.3100(2)$ & $1.0629(3)$ & $0.34103(15)$ & $0.0266(9)$ \\
\hline C(1) & $0.1535(3)$ & $0.7090(3)$ & $0.23361(19)$ & $0.0278(11)$ \\
\hline$C(2)$ & 132913 & $0.7138(4)$ & $0.1680(2)$ & $0.0389(14)$ \\
\hline & & & & \\
\hline C(4) & $0.2751(4)$ & $0.5537(4)$ & $0.2089(3)$ & $0.0490(17)$ \\
\hline$C(5)$ & $0.3397(5)$ & $0.4730(5)$ & $0.1952(4)$ & $0.085(3)$ \\
\hline$C(6)$ & 0.2 & 74(4) & $0.2716(2)$ & $6(14)$ \\
\hline$C(7)$ & & $10(4)$ & $8(2)$ & $7(14)$ \\
\hline$C(8)^{b}$ & $47(5)$ & $0.6400(6)$ & $0.3662(3)$ & $0(17)$ \\
\hline$C(9)^{b}$ & & & & \\
\hline$C(10)^{b}$ & 0.3 & 0.6 & 0.4 & \\
\hline$C(11)$ & 0.04 & 0.7 & & (19) \\
\hline$C(12)$ & -0.14 & $0.8346(4)$ & $3(2)$ & $0(16)$ \\
\hline$C(13)$ & -0.0 & 0.6 & & $9(19)$ \\
\hline (14) & & & & $8(10)$ \\
\hline$C(1$ & & & $044(17)$ & $41(11)$ \\
\hline$C(16)$ & 0.35 & $1.1663(3)$ & $06(18)$ & $0(11)$ \\
\hline$C(17)$ & & & & (11) \\
\hline $\mathrm{C}(1$ & 0.4 & 1.3 & 0.5 & $0(12)$ \\
\hline C(19) & & $1.2461(3)$ & $0.49231(18)$ & 34(11) \\
\hline$C(20)$ & 0.14 & $1.1700(3)$ & $0.43284(17)$ & 38(11) \\
\hline $\mathrm{C}(2$ & & $1.1695(4)$ & $79(18)$ & $05(11)$ \\
\hline$C(22)$ & -0.0 & 1.31 & 0.3 & $0.0600(17)$ \\
\hline$C(23)$ & -0.163 & $1.2025(6)$ & & $10(16)$ \\
\hline$C(24)$ & 0.3190 & $1.0040(3)$ & $69(18)$ & $72(11)$ \\
\hline$C(25)$ & & & & $1(12)$ \\
\hline$C(26)$ & 0.34 & 0.968 & 0.31 & $2(12)$ \\
\hline$C(81)^{c}$ & $0.2047(8)$ & $0.5592(10)$ & $0.3372(5)$ & $0.044(4)$ \\
\hline$C(91)^{c}$ & $0.3728(7)$ & & $0.4399(6)$ & \\
\hline$C(101)^{c}$ & $0.2478(12)$ & $0.5760(12)$ & $0.4527(7)$ & $0.056(5)$ \\
\hline \multicolumn{5}{|c|}{ Benzene Solve } \\
\hline & & & & \\
\hline$C(31)$ & $0.4188(5)$ & 1.0 & $0.1910(3)$ & \\
\hline & & $1.1419(8)$ & $1 / 4$ & $0.090(4)$ \\
\hline C(33) & & $0.8839(8)$ & 14 & $0.089(5)$ \\
\hline
\end{tabular}

- $U($ eq $)=$ one-third of the trace of the orthogonalized $U$ tensor ${ }^{b}$ Indicates disordered atoms with sof $=0.566(7) .{ }^{c}$ Indicates disordered atoms with sof $=0.434(7)$.

Table VI. Selected Geometrical Data for $\left[\mathrm{NaOC}_{6} \mathrm{H}_{2}\left(\mathrm{CH}_{2} \mathrm{NMe}_{2}\right)_{2}-2,6-\mathrm{Me}-4\right]_{4} \cdot \mathrm{C}_{6} \mathrm{H}_{6}(2 \mathrm{c})^{a}$

\begin{tabular}{llll} 
& \multicolumn{4}{c}{ Bond Lengths $(\AA)$} \\
$\mathrm{Na}(1)-\mathrm{O}(1)$ & $2.344(3)$ & $\mathrm{Na}(2)-\mathrm{O}(1)$ & $2.417(2)$ \\
$\mathrm{Na}(1)-\mathrm{O}(2)$ & $2.351(2)$ & $\mathrm{Na}(2)-\mathrm{O}(2)$ & $2.339(3)$ \\
$\mathrm{Na}(1)-\mathrm{O}(1 \mathrm{a})$ & $2.325(4)$ & $\mathrm{Na}(2)-\mathrm{O}(2 \mathrm{a})$ & $2.348(3)$ \\
$\mathrm{Na}(1)-\mathrm{N}(1)$ & $2.494(5)$ & $\mathrm{Na}(2)-\mathrm{N}(4)$ & $2.640(4)$ \\
$\mathrm{Na}(1)-\mathrm{N}(2 \mathrm{a})$ & $2.664(5)$ & $\mathrm{Na}(2)-\mathrm{N}(3 \mathrm{a})$ & $2.468(3)$ \\
$\mathrm{O}(1)-\mathrm{C}(1)$ & $1.324(6)$ & $\mathrm{O}(2)-\mathrm{C}(14)$ & $1.324(4)$
\end{tabular}

$\mathrm{O}(1)-\mathrm{Na}(1)-\mathrm{O}(2)$

Bond Angles (deg)

$91.86(10) \quad \mathrm{O}(1)-\mathrm{Na}(2)-\mathrm{O}(2)$

$90.33(10)$

$\mathrm{O}(1)-\mathrm{Na}(1)-\mathrm{O}(1 \mathrm{a})$

$90.69(11) \quad \mathrm{O}(1)-\mathrm{Na}(2)-\mathrm{O}(2 \mathrm{a})$

$89.74(10)$

$91.93(10) \quad \mathrm{O}(2)-\mathrm{Na}(2)-\mathrm{O}(2 \mathrm{a}) \quad 93.16(12)$

$\mathrm{Na}(1)-\mathrm{O}(1)-\mathrm{Na}(2) \quad 88.03(10) \quad \mathrm{Na}(1)-\mathrm{O}(2)-\mathrm{Na}(2) \quad 89.73(10)$

$\mathrm{Na}(1)-\mathrm{O}(1)-\mathrm{Na}(1 \mathrm{a}) \quad 89.28(14) \quad \mathrm{Na}(1)-\mathrm{O}(2)-\mathrm{Na}(2 \mathrm{a}) \quad 89.66(10)$

$\mathrm{Na}(1 \mathrm{a})-\mathrm{O}(1)-\mathrm{Na}(2) \quad 88.59(10) \quad \mathrm{Na}(2)-\mathrm{O}(1)-\mathrm{Na}(2 \mathrm{a}) \quad 86.82(9)$

$\mathrm{C}(1)-\mathrm{O}(1)-\mathrm{Na}(1) \quad 132.3(2) \quad \mathrm{C}(14)-\mathrm{O}(2)-\mathrm{Na}(2) \quad 116.3(3)$

$\mathrm{C}(1)-\mathrm{O}(1)-\mathrm{Na}(1 \mathrm{a}) \quad 119.3(2) \quad \mathrm{C}(14)-\mathrm{O}(2)-\mathrm{Na}(2 \mathrm{a}) \quad 134.1(3)$

$a$ a indicates the symmetry operation: $-x, y, 1 / 2-z$.

\section{Discussion}

According to the elegant studies by Jackman et al., steric effects are very important in controlling the degree of aggregation of lithium phenolates. ${ }^{5,7}$ Seebach et al. pointed out that there is a strong electrostatic driving force for the formation of tetramers over less highly-aggregated species. ${ }^{13 \mathrm{~b}}$ The introduction of two ortho-substituents changes this situation dramatically, e.g. lithium

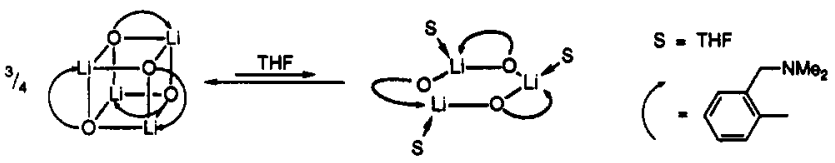

Figure 5. Proposed tetramer/trimer equilibrium for the mono-orthochelated lithium phenolates in THF at low temperature.

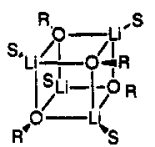

I

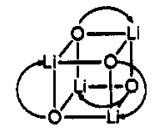

$H\left(S_{4}\right)$

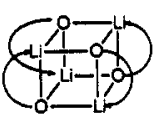

III $\left(D_{2}\right)$

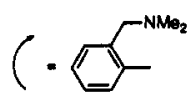

Figure 6. Schematical representation of tetrameric aggregates in which the lithium atom is four-coordinate: (i) aggregate with coordinating solvent molecules present (S); (ii and iii) two geometrically different isomers of intramolecular chelated lithium phenolate tetramers.

2,6-dimethylphenolate is a dimer in weakly polar aprotic solvents. ${ }^{5}$ When steric crowding is increased, as in lithium 2,6-di-tertbutylphenolate, the complex is still a dimer in ethereal solutions. ${ }^{12}$ However, monomeric species were observed at low temperatures and concentrations in dioxolane and even at room temperature in pyridine. ${ }^{5}$ In the present study, the introduction of a $\mathrm{CH}_{2-}$ $\mathrm{NMe}_{2}$ substituent in one (see Figure $1 \mathrm{a}, \mathrm{b}$ ) or in both orthopositions (see Figure 1c) adds a coordinative interaction to the steric hindrance. This interaction appears to determine the structures of the resulting phenolate complexes.

Structures in Solution. In the lithium phenolate 1a, one large ortho-substituent is present, containing a potentially coordinating tertiary amine group, whereas in $\mathbf{1 b}$ a ligand is present that is sterically comparable with 2,6 -dimethylphenolate, except that one of the methyl groups likewise contains a coordinating amine function. Cryoscopy shows that these complexes are tetrameric in solution, indicating the overruling importance of $\mathrm{Li}-\mathrm{N}$ coordination. A similar result was obtained for a lithium phenolate containing a chelating 2-methoxymethyl group. ${ }^{7}$ However, at low temperature and at low concentrations in THF, 1a coexists with a second species. The $\Delta_{\delta \mathrm{C}(4)}$ values $\left(i . e . \delta_{\mathrm{C}(4)}\right.$-anisole $-\delta_{\mathrm{C}(4)}$ phenolate) $)^{5}$ for both species are 5.0 and 7.0 , respectively, indicating that most probably a tetramer/trimer equilibrium is present under these conditions. A trimeric structure in which mono-orthochelated phenolate ligands are present implies that the lithium atoms are three-coordinate. We, therefore, propose that, besides the three intramolecular coordinating tertiary amine groups, also three THF molecules coordinate to the lithium atoms, see Figure 5.

When the 0 -methyl group in $\mathbf{1 b}$ is replaced by a second orthochelating (dimethylamino)methyl group as in 1c, the degree of association in solution is three, corresponding to a lithium phenolate with a stable, trinuclear structure. Again, the chelating properties of the $o$-amine substituent stabilize the trimeric lithium phenolate, underlining the different influences of noncoordinating versus potentially coordinating ortho-substituents on the structures of these phenolates. The influence of the cation size appears from the different aggregates formed in the case of the bis-orthochelated lithium and sodium phenolates.

The two species present in apolar solutions of the lithium phenolates 1a,b, are both tetrameric. The concentration independency of the molar ratio of both species also suggests that they have the same degree of association. In Figure 6 three possible tetrameric structures are depicted. In compound $i$, coordinating solvent molecules (S) occupy the fourth coordination site on the lithium atoms. Examples of this type of tetramer are two lithium enolate complexes, i.e. lithium 3,3-dimethyl-1-buten2-olate and lithium cyclopentenolate THF solvates. ${ }^{13}$

In structures ii and iii, the fourth coordination site is occupied by an intramolecularly coordinating group, like the dimethylamine group in 1a,b. As depicted in Figure 6 this intramolecular Li-N coordination may lead to two possible species: one with $S_{4}$ symmetry and one with $D_{2}$ symmetry (structures ii and iii, 


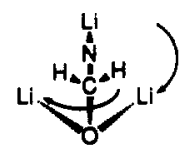

H $\left(S_{4}\right)$
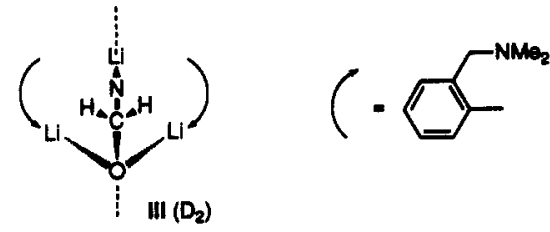

Figure 7. Fragments of tetramer ii and iii in which the plane of symmetry through the benzylic carbon atom, ii, or its absence, iil, is visualized.
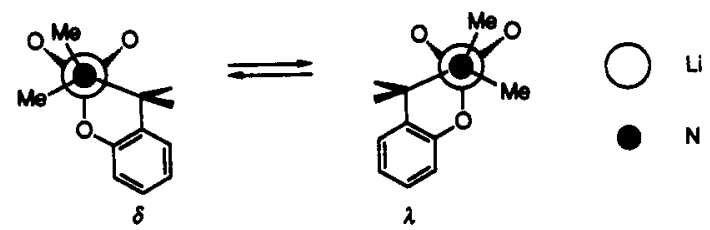

Figure 8. Interconversion between ring conformers, $\delta$ and $\lambda$, in a sixmembered chelate-ring.

respectively). Examples of tetranuclear species with $S_{4}$ symmetry are the lithium 2-[2-\{(dimethylamino)methyl $\}$ phenyl]-1-ethen2-olate tetramer ${ }^{17}$ and the complex of a lithium aldolate derived from the reaction of the lithium enolate of pinacolone with pivaldehyde. ${ }^{18}$ To our knowledge, no examples are known of tetrameric lithium enolates or phenolates of the $D_{2}$ type, but two organolithium complexes have been reported that essentially have a tetrameric $D_{2}$ structure. ${ }^{19}$

The tetramers with $S_{4}$ and $D_{2}$ symmetry are distinguishable because the NMR spectra of the isomers differ with respect to the resonance patterns for the $\mathrm{CH}_{2} \mathrm{~N}$ hydrogens and the $\mathrm{NMe}_{2}$ methyl groups. For example, the $\mathrm{CH}_{2} \mathrm{~N}$ hydrogens and the $\mathrm{NMe}_{2}$ methyl groups for the major isomer of $1 \mathrm{a}$ (and the minor isomer for 1b) are diastereotopic, indicating that $\mathrm{Li}-\mathrm{N}$ coordination is present (within the limits of the NMR time scale), and that a plane of symmetry through the benzylic carbon atom is absent (isomer with $S_{4}$ symmetry, see Figure 7). In addition, the resonances for the minor isomer of $1 \mathrm{a}$ (and the major isomer for 1b), i.e. a singlet for both the $\mathrm{CH}_{2} \mathrm{~N}$ hydrogens and the $\mathrm{NMe}_{2}$ methyl groups, are in accordance with a tetrameric structure having $D_{2}$ symmetry.

However, when solutions of $1 \mathrm{a}, \mathrm{b}$ in toluene- $d_{8}$ are cooled to $-40^{\circ} \mathrm{C}$, the signals originating from the aggregate with $D_{2}$ symmetry decoalesce as well. This can be understood if we take the puckering of the six-membered chelate-ring into account. This process was also found in triorganotin halides containing a six-membered chelate ring ${ }^{20}$ and in the inorganic tungsten(VI) phenylimido complex $\mathrm{WCl}_{3}(=\mathrm{NPh})\left(\mathrm{OC}_{6} \mathrm{H}_{4} \mathrm{CH}_{2} \mathrm{NMe}_{2}-2\right)^{21}$ containing ligand $a$. Figure 8 shows the two isomers, $\delta$ and $\lambda$, which are in the fast-exchange limit at elevated temperatures. When the temperature is lowered, this ring-flipping process is slowed down until finally the slow-exchange limit is reached. This feature becomes apparent in the NMR spectrum as an AB pattern for the benzylic protons and two distinctive signals for the aminomethyl groups.

The influence of the introduction of two methyl groups in ligand b manifests itself in the difference in the molar ratio of the two tetrameric aggregates of complexes $1 \mathrm{a}$ and $1 \mathrm{~b}$ in toluene at room temperature, the $S_{4}: D_{2}$ ratio being $3: 1$ for $1 \mathrm{a}$ and $1: 4$ for $1 \mathrm{~b}$, respectively. This difference is most probably caused by steric interaction between these methyl groups, but no satisfactory explanation can be given.

(17) Jastrzebski, J. T. B. H.; Van Koten, G.; Christophersen, M. J. N.; Stam, C. H. J. Organomet. Chem. 1985, 292, 319.

(18) Williard, P. G.; Salvino, J. M. Tetrahedron Lett. 1985, 26, 3931.

(19) (a) Klumpp, G. W.; Vos, M.; De Kanter, F. J. J.; Slob, C.; Krabbendam, H.; Spek, A. L. J. Am. Chem. Soc. 1985, 102, 99. (b) Klumpp, G. W. Recl. Trav. Chim. Pays-Bas 1986, 105, 1. (c) Lee, K. S.; Williard, P. G.; Suggs, J, W. J. Organomet. Chem. 1986, 299, 311.

(20) van Koten, G.; Jastrzebski, J. T. B. H.; Noltes, J. G.; Verhoeckx, G. J.; Spek, A. L.; Kroon, J. J. Chem. Soc., Dalton Trans. 1980, 1352.

(21) van der Schaaf, P. A.; Smeets, W. J. J.; Spek, A. L.; van Koten, G. Inorg. Chem., in press.
Scheme III

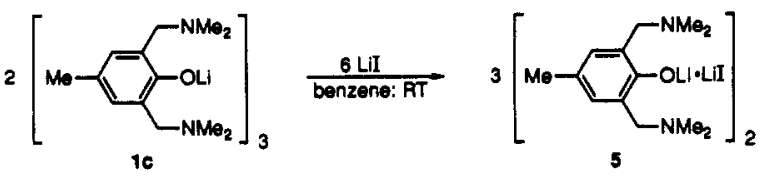

Solid-State Structures. The structure of $1 \mathrm{c}$ seems to be related to the earlier reported trimeric structures of 2,6-bis(dimethylamino)phenyllithium, ${ }^{22}$ and bis(trimethylsilyl)amidolithium. ${ }^{23}$ In the last two complexes the values of the $\mathrm{N}-\mathrm{Li}-\mathrm{N}$ angles are close to those of the $\mathrm{C}-\mathrm{Li}-\mathrm{C}$ angles $\left(147(3)\right.$ and $149.4(3)^{\circ}$, respectively), and the same is true for the values of the $\mathrm{Li}-\mathrm{N}-\mathrm{Li}$ and $\mathrm{Li}-\mathrm{C}-\mathrm{Li}$ angles $\left(92(2)\right.$ and $90.3(2)^{\circ}$, respectively). In 1c the corresponding $\mathrm{O}-\mathrm{Li}-\mathrm{O}$ and $\mathrm{Li}-\mathrm{O}-\mathrm{Li}$ angles are $111.5(4)$ and $128.5(4)^{\circ}$, respectively. Because of the flexibility of the orthochelating (dimethylamino)methyl groups, the six-membered ring of $1 \mathrm{c}$ is less distorted than those of the above mentioned trimers, and $\Sigma^{\circ}$ is exactly $720.0^{\circ}$.

The short bond lengths in 1c can be understood when the planarity of the six-membered $\mathrm{Li}_{3} \mathrm{O}_{3}$ ring is taken into account (see view b in Figure 2; the maximum least-square deviation is $0.05(2) \AA$ ). Recently, Power published a review about heteroatom-containing six-membered ring systems which are described in terms of "quasi-aromaticity".24 Complex $1 \mathrm{c}$ can also be regarded as "quasi-aromatic" when the lone pairs of the oxygen atoms are considered as delocalized $\pi$-electrons. The shortening of the bond lengths between lithium and oxygen is then related to a change of hybridization of the oxygen atoms from pure $\mathrm{sp}^{3}$ to $\mathrm{sp}^{2}$-like.

Although the trimeric structure of 1c seems extremely stable, the addition of lithium iodide to a benzene solution of $1 \mathrm{c}$ leads to the quantitative formation of the corresponding tetranuclear 1:1 LiI-adduct of 1c, complex 5, see Scheme III. ${ }^{10}$ The sodium analog $2 c$ does not show this behavior of forming mixed phenolatehalide sodium aggregates. This makes $2 c$ more suitable than $1 c$ in methathesis reactions with metal halides. For example, the reaction of $\mathrm{WCl}_{4}(\mathrm{NPh})\left(\mathrm{OEt}_{2}\right)$ with $1 \mathrm{c}$ needs 2 equiv of $1 \mathrm{c}$ to produce a 1:1 mixture of $\mathrm{WCl}_{3}(\mathrm{NPh})\left(\mathrm{OC}_{6} \mathrm{H}_{2}\left(\mathrm{CH}_{2} \mathrm{NMe}_{2}\right)_{2}\right.$-2,6$\mathrm{Me}-4)$ and 5 while the $1: 1$ reaction of $\mathrm{WCl}_{4}(\mathrm{NPh})\left(\mathrm{OEt}_{2}\right)$ with $2 c$ produces quantitatively $\mathrm{NaCl}$ and the tungsten phenolate.

Complex 5 is a tetranuclear species in the solid-state with a distorted $\mathrm{Li}_{4}$ tetrahedron. ${ }^{10}$ The $\mathrm{C}_{i p s o}-\mathrm{O}$ and $\mathrm{Li}-\mathrm{O}$ distances of $1.918(9) \AA$ (average) and $1.355(5) \AA$, respectively, are significantly longer than those in 1c, but are comparable with those reported earlier for lithium phenolates and enolates. ${ }^{12,13}$

In general, the coordination number of sodium varies from 4 to 8, whereas lithium atoms prefer four-coordination. ${ }^{25,26}$ This difference is mainly caused by the larger radius of the sodium cation. ${ }^{25}$ As a result, the ortho-chelating $\mathrm{CH}_{2} \mathrm{NMe}_{2}$ groups of only two "pincer-phenolate" ligands are capable to bridge to the sodium atom, thus enabling dimer formation (as found in solution). In such a dimer the sodium atoms are four-coordinate as a result of bonding to two bridging phenolate oxygens and two intramolecular $\mathrm{Na}-\mathrm{N}$ coordinative bonds. When a tetranuclear species is formed, like in the solid-state structure of $2 c$, this occurs by formation of additional phenolate-oxygen bonds between the dimeric units resulting in five-coordination at the sodium atoms. At present we consider the solid-state structure of $2 \mathrm{c}$ as a double dimer in which such additional "interdimeric" $\mathrm{Na}-\mathrm{O}$ bonds are present. However, the $\mathrm{Na}-\mathrm{O}$ bond distances between the dimer

(22) Harder, S.; Boersma, J.; Brandsma, L.; Kanters, J. A.; Bauer, W.; Schleyer, P. v. R. Organometallics 1989, 8, 1696.

(23) (a) Mootz, D.; Zinnius, A.; Böttcher, B. Angew. Chem. 1969, 81, 398. (b) Rogers, R. D.; Atwood, J. L.; Grüning, R. J. Organomet. Chem. 1978, $157,229$.

(24) (a) Power, P. P. J. Organomet. Chem. 1990, 400, 49. (b) Olmsead, M. M.; Power, P. P.; Shoner, S. C. J. Am. Chem. Soc. 1991, 113, 3379. (25) Schade, C.; Schleyer, P. v. R. Adv. Organomet. Chem. 1987, 27, 169.

(26) Fenton, D. E. In Comprehensive Coordination Chemistry; Wilkinson, G., Ed.; Pergamon Press: Oxford, England, 1987; Vol. 3. 
subunits are not significantly longer with respect to the bond lengths within each of the dimer subunits. The difference in degree of association of $\mathbf{2 c}$ in solution and in the solid state is most probably caused by preferential crystallization of a slightly soluble tetrameric species, which is present in small quantities in solution of $2 \mathrm{c}$ at room temperature. However, the equilibrium must lie far to the dimeric side, since no evidence for tetramers was found with cryoscopy or by room temperature NMR spectroscopy.

\section{Experimental Section}

General Data. All reactions were carried out in an atmosphere of dry, deoxygenated nitrogen, using standard Schlenk techniques. Solvents were dried over sodium benzophenone ketyl and distilled prior to use. Commercially available reagents were used as supplied, $n-\mathrm{BuLi}$ (1.6 M in hexane) was obtained from Aldrich Chemical Co. Cryoscopic measurements were performed in benzene under an inert atmosphere (the accuracy of these measurements is estimated to be about $5 \%)$. ${ }^{1} \mathrm{H}$ and ${ }^{13} \mathrm{C}$ NMR spectra were recorded on a Bruker $\mathrm{AC} 200$ or $\mathrm{AC} 300$ spectrometer at room temperature unless otherwise noted. Elemental analyses were carried out at the Institute for Applied Chemistry TNO, Zeist, The Netherlands, or by Mikroanalytisches Laboratorium Dornis und Kolbe, Mülheim a. d. Ruhr, Germany.

Synthesis of the Phenols. 2-[(Dimethylamino)methyl]phenol (a). This phenol was synthesized via a procedure described in the literature. ${ }^{11}$ The reaction of phenol $(0.25 \mathrm{~mol})$ with 1 equiv of formaldehyde and dimethylamine in water (total volume 0.5 L) gives a, after distillation (bp $98^{\circ} \mathrm{C}(11 \mathrm{~mm})$; lit. ${ }^{1 \text { la }}$ bp 104 ${ }^{\circ} \mathrm{C}(13 \mathrm{~mm})$ ) and a washing procedure with $0.5 \mathrm{M} \mathrm{NaOH}$ solution in water, in $65 \%$ yield. Anal. Calcd for $\mathrm{C}_{9} \mathrm{H}_{13} \mathrm{NO}$ : $\mathrm{C}, 71.49$; $\mathrm{H}, 8.67$; N, 9.26. Found: C, 71.36; H, 8.76; N, 9.32. NMR data in benzene- $d_{6} .{ }^{1} \mathrm{H}$ NMR: $\delta 10.9(\mathrm{~s}, 1, \mathrm{OH}), 7.14-6.71(2 \mathrm{~m}$, 4, Ar-H), 3.17 (s, 2, $\left.\mathrm{CH}_{2} \mathrm{~N}\right), 1.76\left(\mathrm{~s}, 6, \mathrm{NMe}_{2}\right),{ }^{13} \mathrm{C} \mathrm{NMR}: \delta$ $159.1\left(\mathrm{C}_{i p s o}\right), 129.2,128.6,122.3,119.1,116.6(\mathrm{Ar}-\mathrm{C}), 62.9$ $\left(\mathrm{CH}_{2} \mathrm{~N}\right), 44.0\left(\mathrm{NMe}_{2}\right)$.

2-[(Dimethylamino)methyl]-4,6-dimethylphenol (b). This phenol was synthesized starting from 2,4-dimethylphenol via a procedure similar to the one described for a (yield $95 \%$ on a 0.25 mol scale). The usage of a $50 \%$ excess of formaldehyde and dimethylamine renders the washing procedure with a $0.5 \mathrm{M} \mathrm{NaOH}$ sodium superfluous (bp $55^{\circ} \mathrm{C}(0.1 \mathrm{~mm})$; lit. ${ }^{27}$ bp $90^{\circ} \mathrm{C}(0.9$ mm)). Anal. Calcd for $\mathrm{C}_{11} \mathrm{H}_{17} \mathrm{NO}: \mathrm{C}, 73.70 ; \mathrm{H}, 9.56 ; \mathrm{N}, 7.81$. Found: $C, 73.76 ; H, 9.59 ; \mathrm{N}, 7.88$. NMR data in benzene- $d_{6}$. ${ }^{1} \mathrm{H}$ NMR: $\delta 8.8(\mathrm{~s}, 1, \mathrm{OH}), 6.85,6.52(2 \mathrm{~s}, 2, m-\mathrm{H}), 3.21(\mathrm{~s}, 2$, $\left.\mathrm{CH}_{2} \mathrm{~N}\right), 2.40$ (s, 3,o-Me), 2.18 (s, 3, p-Me), 1.83 (s, 6, $\mathrm{NMe}_{2}$ ). ${ }^{13} \mathrm{C}$ NMR: $\delta 154.6\left(\mathrm{C}_{\text {ipso }}\right), 131.1,127.2,126.8,124.8,121.2$ $(\mathrm{Ar}-\mathrm{C}), 63.1\left(\mathrm{CH}_{2} \mathrm{~N}\right), 44.0\left(\mathrm{NMe}_{2}\right), 20.6(p-\mathrm{Me}), 16.1(o-\mathrm{Me})$.

2,6-Bis [(dimethylamino)methyl]-4-methylphenol (c). This phenol was synthesized starting from 4-methylphenol via a procedure similar to the one described for b (yield $96 \%$ on a $0.5 \mathrm{~mol}$ scale) (bp $80^{\circ} \mathrm{C}(0.1 \mathrm{~mm})$; lit. ${ }^{11 a}$ bp $134^{\circ} \mathrm{C}(3 \mathrm{~mm})$ ). Anal. Calcd for $\mathrm{C}_{13} \mathrm{H}_{22} \mathrm{~N}_{2} \mathrm{O}: \mathrm{C}, 70.23 ; \mathrm{H}, 9.97 ; \mathrm{N}, 12.60$. Found: $\mathrm{C}, 70.16$; $\mathrm{H}, 10.04 ; \mathrm{N}, 12.71$. NMR data in benzene- $d_{6}$. ${ }^{1} \mathrm{H}$ NMR: $\delta 10.5$ (br, 1, OH), $6.98(\mathrm{~s}, 2, m-\mathrm{H}), 3.48\left(\mathrm{~s}, 4, \mathrm{CH}_{2} \mathrm{~N}\right), 2.21$ (s, 3, p-Me), 2.04 (s, 12, $\left.\mathrm{NMe}_{2}\right)$. ${ }^{13} \mathrm{C}$ NMR: $\delta 154.7\left(\mathrm{C}_{i p s o}\right), 129.3$, 127.3, $123.8(\mathrm{Ar}-\mathrm{C}), 60.3\left(\mathrm{CH}_{2} \mathrm{~N}\right), 44.9\left(\mathrm{NMe}_{2}\right), 22.8(p-\mathrm{Me})$.

Synthesis of the Lithium and Sodium Phenolates. [ $\mathrm{Li}\left(\mathrm{OC}_{6} \mathrm{H}_{4}-\right.$ $\left.\mathrm{CH}_{2} \mathrm{NMe}_{2}-2\right)$ ] (1a). A $1.6 \mathrm{M}$ solution of $n-\mathrm{BuLi}$ in hexane (46.4 $\mathrm{mL}, 74.2 \mathrm{mmol}$ ) was added dropwise to a solution of a $(11.2 \mathrm{~g}$, $71.1 \mathrm{mmol})$ in hexane $(50 \mathrm{~mL})$ at $-78^{\circ} \mathrm{C}$. After warming up to room temperature, the reaction mixture was filtered and the white residual solid was washed with pentane $(2 \times 50 \mathrm{~mL})$; yield $11.4 \mathrm{~g}(98 \%)$. Anal. Calcd for $\mathrm{C}_{9} \mathrm{H}_{12} \mathrm{LiNO}$ : $\mathrm{C}, 68.79 ; \mathrm{H}, 7.70$; $\mathrm{N}, 8.91$. Found: $\mathrm{C}, 68.85 ; \mathrm{H}, 7.73 ; \mathrm{N}, 8.87$. NMR data in methanol- $d_{4}$. ${ }^{1} \mathrm{H}$ NMR: $\delta 6.97,6.96,6.65,6.41(\mathrm{t}, \mathrm{d}, \mathrm{d}, \mathrm{t}, 4$, $\mathrm{Ar}-\mathrm{H}), 3.40\left(\mathrm{~s}, 2, \mathrm{CH}_{2} \mathrm{~N}\right), 2.19$ (s, 6, $\left.\mathrm{NMe}_{2}\right) . .{ }^{13} \mathrm{C} \mathrm{NMR}: \delta$

(27) Gardner, P. D.; Rafsanjani, H. S.; Rand, L. J. Am. Chem. Soc. 1959, $81,3364$.
$166.7\left(\mathrm{C}_{i p s o}\right), 131.6,129.8,126.7,120.1,114.9(\mathrm{Ar}-\mathrm{C}), 62.2$ $\left(\mathrm{CH}_{2} \mathrm{~N}\right), 45.4\left(\mathrm{NMe}_{2}\right)$. NMR data in toluene- $d_{8}$. ${ }^{1} \mathrm{H}$ NMR: $\left(70^{\circ} \mathrm{C}\right) \delta 7.15,6.87,6.64,6.53(\mathrm{t}, \mathrm{d}, \mathrm{d}, \mathrm{t}, 4, \mathrm{Ar}-\mathrm{H}), 3.1(\mathrm{br}, 2$, $\left.\mathrm{CH}_{2} \mathrm{~N}\right) ; 1.86\left(\mathrm{~s}, 6, \mathrm{NMe}_{2}\right) ;\left(-10^{\circ} \mathrm{C}\right) \delta 7.3-6.6(\mathrm{~m}, \mathrm{Ar}-\mathrm{H}), 4.18$ and 2.53 (AB-pattern, $\mathrm{CH}_{2} \mathrm{~N}$ major, ${ }^{2} J_{\mathrm{HH}}=11.7 \mathrm{~Hz}$ ), $3.14(\mathrm{br}$, $\mathrm{CH}_{2} \mathrm{~N}$, minor), 2.33 (s, $o-\mathrm{Me}$, major), 2.28 and 2.26 (2s, $\alpha$ - and p-Me, minor), 2.23 (s, p-Me, major), 1.99 and 1.68 (2s, $\mathrm{NMe}_{2}$, major), 1.8 (br, $\mathrm{NMe}_{2}$, minor). NMR data in THF-d8. ${ }^{1} \mathrm{H}$ NMR: $\left(25^{\circ} \mathrm{C}\right) \delta 7.00,6.88,6.55,6.36(\mathrm{t}, \mathrm{d}, \mathrm{d}, \mathrm{t}, 4, \mathrm{Ar}-\mathrm{H}), 3.39$ $\left(\mathrm{s}, 2, \mathrm{CH}_{2} \mathrm{~N}\right), 2.02\left(\mathrm{~s}, 6, \mathrm{NMe}_{2}\right) ;\left(-60^{\circ} \mathrm{C}\right) \delta 7.00,6.90,6.51,6.35$ (t, d, d, t, 4, Ar-H, major isomer), 7.00, 6.80, 6.49, 6.19 (t, d, $\mathrm{d}, \mathrm{t}, \mathrm{Ar}-\mathrm{H}$ minor), 4.12 and 2.68 (broad $\mathrm{AB}$ pattern, $\mathrm{CH}_{2} \mathrm{~N}$, major, not resolved), 3.25 (br, half $\mathrm{AB}$ pattern, $\mathrm{CH}_{2} \mathrm{~N}$, minor, not resolved); 2.05 (br, $\mathrm{NMe}_{2}$, shoulder; half $\mathrm{AB}$ pattern, $\mathrm{CH}_{2} \mathrm{~N}$, minor, not resolved). ${ }^{13} \mathrm{C}$ NMR: $\left(25^{\circ} \mathrm{C}\right) \delta 166.5\left(\mathrm{C}_{i p s o}\right), 132.3$, $130.1,126.1,120.1,114.7(\mathrm{Ar}-\mathrm{C}), 64.3\left(\mathrm{CH}_{2} \mathrm{~N}\right) ; 44.8\left(\mathrm{NMe}_{2}\right)$; $\left(-60^{\circ} \mathrm{C}\right) \delta 169.9\left(\mathrm{C}_{i p s o}\right.$, minor $), 166.4$ (C $\mathrm{C}_{\text {ipso }}$, major $), 132.5,130.5$, 126.4, 120.4, 114.7 (Ar-C, major), 131.5, 129.7, 127.1, 120.7, 111.7 ( $\mathrm{Ar}-\mathrm{C}$, minor), 64.5 ( $\mathrm{CH}_{2} \mathrm{~N}$, minor), $63.9\left(\mathrm{CH}_{2} \mathrm{~N}\right.$, major), $45.4\left(\mathrm{br}, \mathrm{NMe}_{2}\right)$. Molecular weight determination by cryoscopy $(0.67 \mathrm{~g}$ in 17.32 and $37.30 \mathrm{~g}$ benzene $)$ : calcd for monomer, 157.1 ; found, 619 and 625 (degree of association: 3.95 and 4.00).

[Li( $\left.\left.\mathrm{OC}_{6} \mathrm{H}_{2} \mathrm{CH}_{2} \mathrm{NMe}_{2}-2-\mathrm{Me}_{2}-4,6\right)\right]$ (1b). This complex was prepared via a similar procedure as described above for 1a. The reaction of $18.2 \mathrm{~g}(101.5 \mathrm{mmol}) \mathrm{b}$ and 1 equiv of $n$-BuLi in hexane at $-78{ }^{\circ} \mathrm{C}$ yields $1 \mathrm{~b}$ quantitatively. Anal. Calcd for $\mathrm{C}_{11} \mathrm{H}_{16}$. LiNO: C, 71.43; H, 8.71; N, 7.56. Found: C, 71.27; H, 8.78; $\mathrm{N}, 7.53$. NMR data in methanol- $d_{4}$. ${ }^{1} \mathrm{H}$ NMR: $\delta 6.73,6.60(2 \mathrm{~s}$, 2, $m-\mathrm{H}), 3.39$ (s, 2, $\left.\mathrm{CH}_{2} \mathrm{~N}\right), 2.19\left(\mathrm{~s}, 6, \mathrm{NMe}_{2}\right), 2.14,2.13$ (2s, $\left.6, \mathrm{Me}_{2}-4,6\right) .{ }^{13} \mathrm{C}\left(25^{\circ} \mathrm{C}\right): \delta 160.6\left(\mathrm{C}_{\text {ipso }}\right), 131.5,129.3,127.0$, 124.7, 124.1 (Ar-C), 63.1 $\left(\mathrm{CH}_{2} \mathrm{~N}\right), 45.3\left(\mathrm{NMe}_{2}\right), 20.8,17.5$ $\left(\mathrm{Me}_{2}-4,6\right)$. NMR data in toluene- $d_{8}$. ${ }^{1} \mathrm{H}$ NMR: $\left(80^{\circ} \mathrm{C}\right) \delta 6.92$, $6.57(2 \mathrm{~s}, 2, m-\mathrm{H}), 3.28\left(\mathrm{br}, 2, \mathrm{CH}_{2} \mathrm{~N}\right), 2.38(\mathrm{~s}, 3, \sigma-\mathrm{Me}), 2.18$ (s, 3, p-Me), $1.60\left(\mathrm{~s}, 6, \mathrm{NMe}_{2}\right) ;\left(25^{\circ} \mathrm{C}\right) \delta 7.01(\mathrm{~s}, m-\mathrm{H}$, minor and major isomer), 6.69 (s, $m-\mathrm{H}$, minor), 6.61 (s, $m-\mathrm{H}$, major), 4.59 and 2.48 (AB pattern, $\mathrm{CH}_{2} \mathrm{~N}$ minor, ${ }^{2} \mathrm{~J}_{\mathrm{HH}}=11.6 \mathrm{~Hz}$ ), 4.1 (br, half $\mathrm{AB}$ pattern $\mathrm{CH}_{2} \mathrm{~N}$, major), 2.33 (s, $o$-Me, major), 2.28 and 2.26 (2s, o- and $p$-Me, minor), 2.23 (s, $p$-Me, major), 1.85 and 1.63 (2s, $\mathrm{NMe}_{2}$, minor), 1.8 (br, $\mathrm{NMe}_{2}$, major). ${ }^{13} \mathrm{C} \mathrm{NMR}$ : $\left(80^{\circ} \mathrm{C}\right) \delta 162.0\left(\mathrm{C}_{i p s o}\right), 137.4,131.9,131.4,123.9,122.4(\mathrm{Ar}-$ C), $65.0\left(\mathrm{CH}_{2} \mathrm{~N}\right), 44.7\left(\mathrm{NMe}_{2}\right), 20.3(p-\mathrm{Me}), 18.7(0-\mathrm{Me}) ;(25$ $\left.{ }^{\circ} \mathrm{C}\right) \delta 162.1$ ( $\mathrm{C}_{\text {ipso, }}$ minor), 162.0 (C $\mathrm{C}_{\text {ipso, }}$ major), 137.4-122.3 (Ar-C), 65.1 ( $\mathrm{CH}_{2} \mathrm{~N}$, major $), 64.1\left(\mathrm{CH}_{2} \mathrm{~N}\right.$, minor $), 46.7$ and 43.9 ( $2 \mathrm{~s}, \mathrm{NMe}$, minor), 46 and 43 ( 2 br s, NMe, major), 20.5 and 18.9 ( $\mathrm{Me}_{2}-4,6$, major), 18.3 (Me-4 or -6 , minor, second signal covered by solvent signals). NMR data in THF- $d_{8}$. ${ }^{1} \mathrm{H}$ NMR: $\left(25^{\circ} \mathrm{C}\right) \delta 6.72,6.52(2 \mathrm{~s}, 2, \mathrm{Ar}-\mathrm{H}), 3.27\left(\mathrm{br} \mathrm{s}, 2, \mathrm{CH}_{2} \mathrm{~N}\right), 2.15$, $2.10\left(2 \mathrm{~s}, 6, \mathrm{Me}_{2}-4,6\right), 2.09$ (br s, 6, $\left.\mathrm{NMe}_{2}\right) ;\left(-60^{\circ} \mathrm{C}\right) \delta 6.70,6.53$ (2s, 2, Ar-H), 3.9 and 2.5 (br AB pattern, $2, \mathrm{CH}_{2} \mathrm{~N}$, not resolved), 2.12, $2.10\left(2 \mathrm{~s}, 6, \mathrm{Me}_{2}-4,6\right), 2.1\left(\mathrm{br}, \mathrm{NMe}_{2}\right) .{ }^{13} \mathrm{C} \mathrm{NMR}:\left(25^{\circ} \mathrm{C}\right)$ $\delta 165.3\left(\mathrm{C}_{\text {ipso }}\right), 131.4,130.1,126.2,124.4,118.6(\mathrm{Ar}-\mathrm{C}), 64.9$ $\left(\mathrm{CH}_{2} \mathrm{~N}\right), 45.4\left(\mathrm{NMe}_{2}\right), 20.8,18.5\left(\mathrm{Me}_{2}-4,6\right) ;\left(-60^{\circ} \mathrm{C}\right) \delta 165.4$ $\left(\mathrm{C}_{\text {ipso }}\right), 131.4,130.1,126.4,124.4,118.3(\mathrm{Ar}-\mathrm{C}), 64.6\left(\mathrm{CH}_{2} \mathrm{~N}\right)$, 46.5 and 44.0 ( $\mathrm{NMe}_{2}$, just decoalesced), 21.2, $19.2\left(\mathrm{Me}_{2}-4,6\right)$. Molecular weight determination by cryoscopy $(0.52 \mathrm{~g}$ in 19.81 and $55.96 \mathrm{~g}$ benzene): calcd for monomer, 185.2 ; found, 722 and 712 (degree of association: 3.90 and 3.85).

$\left[\mathrm{Li}\left\{\mathrm{OC}_{6} \mathrm{H}_{2}\left(\mathrm{CH}_{2} \mathrm{NMe}_{2}\right)_{2}-2,6-\mathrm{Me}-4\right\}\right]$ (1c). This complex was prepared via a procedure similar to that described for 1a. The reaction of $19.3 \mathrm{~g}(86.5 \mathrm{mmol})$ of $\mathbf{c}$ and 1 equiv of $n-\mathrm{BuLi}$ in hexane (total volume is $100 \mathrm{~mL}$ ) gives the crude product which was washed with cold pentane $(2 \times 20 \mathrm{~mL})$. Yield: $18.5 \mathrm{~g}(94 \%)$. The product can be crystallized from hot hexane. Suitable crystals for an X-ray diffraction study were obtained by very slow concentration of a saturated toluene solution. Anal. Calcd for $\mathrm{C}_{13} \mathrm{H}_{21} \mathrm{LiN}_{2} \mathrm{O}: \mathrm{C}, 68.40 ; \mathrm{H}, 9.27 ; \mathrm{N}, 12.27$. Found: $\mathrm{C}, 68.32$; $\mathrm{H}, 9.08 ; \mathrm{N}, 12.15$. NMR data in benzene- $d_{6} .{ }^{1} \mathrm{H}$ NMR: $\delta 6.93$ (s, 2, m-H), 3.32 (br s, 4, $\left.\mathrm{CH}_{2} \mathrm{~N}\right), 2.34$ (s, 3,p-Me), 1.92 (s, 12, $\left.\mathrm{NMe}_{2}\right)$. ${ }^{13} \mathrm{C}$ NMR: $\delta 165\left(\mathrm{C}_{\text {ipso }}\right), 131.1,126.6,118.9(\mathrm{Ar}-\mathrm{C})$, $64.0\left(\mathrm{CH}_{2} \mathrm{~N}\right), 45.9\left(\mathrm{NMe}_{2}\right), 21.0(p-\mathrm{Me})$. Molecular weight 
determination by cryoscopy $(0.50 \mathrm{~g}$ in 24.22 and $52.56 \mathrm{~g}$ of benzene, $0.037-0.080 \mathrm{M}$ ): calcd for monomer, 228.3 ; found, 660 and 672 (degree of association: 2.90 and 2.95).

$\left[\mathrm{Na}\left(\mathrm{OC}_{6} \mathrm{H}_{2} \mathrm{CH}_{2} \mathrm{NMe}_{2}-2\right)\right](2 \mathrm{a})$. This complex was obtained quantitatively after addition of a (10\% excess) to a suspension of $\mathrm{NaH}$ in pentane (ca. $60 \mathrm{mmol}$, in $50 \mathrm{~mL}$ ). Anal. Calcd for $\mathrm{C}_{9} \mathrm{H}_{12} \mathrm{NNaO}: \mathrm{C}, 62.42 ; \mathrm{H}, 6.98 ; \mathrm{N}, 8.09$. Found: $\mathrm{C}, 62.32 ; \mathrm{H}$, 7.10; $\mathrm{N}, 8.11$. NMR data in methanol- $d_{4}$. ${ }^{1} \mathrm{H}$ NMR: $\delta 7.05$, 6.91, 6.65, 6.43 (d, t, d, t, 4, Ar-H), 3.54 (s, 2, $\left.\mathrm{CH}_{2} \mathrm{~N}\right) ; 2.26$ (s, 6, $\left.\mathrm{NMe}_{2}\right) .{ }^{13} \mathrm{CNMR}: \delta 165.8\left(\mathrm{C}_{\text {ipso }}\right), 131.0,129.1,126.1,119.9$, $115.3(\mathrm{Ar}-\mathrm{C}), 59.8\left(\mathrm{CH}_{2} \mathrm{~N}\right), 45.2\left(\mathrm{NMe}_{2}\right)$. NMR data in THF$d_{8}$. 'H NMR: $\left(25^{\circ} \mathrm{C}\right) \delta 6.90,6.84,6.40,6.18(\mathrm{t}, \mathrm{d}, \mathrm{d}, \mathrm{t}, 4$, $\mathrm{Ar}-\mathrm{H}), 3.33\left(\mathrm{~s}, 2, \mathrm{CH}_{2} \mathrm{~N}\right), 2.09\left(\mathrm{~s}, 6, \mathrm{NMe}_{2}\right) ;\left(-60^{\circ} \mathrm{C}\right) \delta 6.85$, 6.77, 6.40, 6.10 (t, d, d, t, Ar-H), $3.5\left(\mathrm{br}, \mathrm{CH}_{2} \mathrm{~N}\right), 2.04$ (br, $\left.\mathrm{NMe}_{2}\right),{ }^{13} \mathrm{CNMR}:\left(25^{\circ} \mathrm{C}\right) \delta 170.4\left(\mathrm{C}_{\text {ipso }}\right), 132.9,129.7,126.1$, $119.9,111.4(\mathrm{Ar}-\mathrm{C}), 64.9\left(\mathrm{CH}_{2} \mathrm{~N}\right), 46.3\left(\mathrm{NMe}_{2}\right) ;\left(-60^{\circ} \mathrm{C}\right) \delta$ $171.2\left(\mathrm{C}_{\text {ipso }}\right), 133.0,129.5,126.2,121.0,110.6$ (Ar-C), 65.2 $\left(\mathrm{CH}_{2} \mathrm{~N}\right), 46.3$ (br, $\left.\mathrm{NMe}_{2}\right)$.

$\left[\mathrm{Na}\left(\mathrm{OC}_{6} \mathrm{H}_{2} \mathrm{CH}_{2} \mathrm{NMe}_{2}-2-\mathrm{Me}_{2}-4,6\right)\right](2 \mathrm{~b})$. This phenolate complex is prepared via a procedure similar to the one described for 2a. Anal. Caled for $\mathrm{C}_{11} \mathrm{H}_{16} \mathrm{NaNO}$ : $\mathrm{C}, 65.65 ; \mathrm{H}, 8.01 ; \mathrm{N}, 6.96$. Found: $\mathrm{C}, 65.68 ; \mathrm{H}, 7.99 ; \mathrm{N}, 7.05$. NMR data in methanol- $d_{4}$. ${ }^{1} \mathrm{H}$ NMR: $\delta 6.72,6.66(2 \mathrm{~s}, 2, \mathrm{~m}-\mathrm{H}), 3.51\left(\mathrm{~s}, 2, \mathrm{CH}_{2} \mathrm{~N}\right), 2.24(\mathrm{~s}$, 6, $\left.\mathrm{NMe}_{2}\right), 2.14\left(\mathrm{~s}, 6, \mathrm{Me}_{2}-4,6\right) .{ }^{13} \mathrm{CNMR}: \delta 158.7\left(\mathrm{C}_{\text {ipso }}\right), 131.1$, $128.5,126.5,125.4,123.9(\mathrm{Ar}-\mathrm{C}), 61.9\left(\mathrm{CH}_{2} \mathrm{~N}\right), 45.0\left(\mathrm{NMe}_{2}\right)$, 20.8, $17.1\left(\mathrm{Me}_{2}-4,6\right)$. NMR data in THF- $d_{8}$. ${ }^{1} \mathrm{H}$ NMR: $(25$ $\left.{ }^{\circ} \mathrm{C}\right) \delta 6.70,6.54(2 \mathrm{~s}, 2, \mathrm{Ar}-\mathrm{H}), 3.22\left(\mathrm{~s}, 2, \mathrm{CH}_{2} \mathrm{~N}\right), 2.08,2.07(2 \mathrm{~s}$, 6, $\left.\mathrm{Me}_{2}-4,6\right), 2.00\left(\mathrm{~s}, 6, \mathrm{NMe}_{2}\right) ;\left(-70{ }^{\circ} \mathrm{C}\right) \delta 6.70,6.53(2 \mathrm{~s}, 2$, $m$-H), 3.9, 2.5 (br AB-pattern, $\mathrm{CH}_{2} \mathrm{~N}$, not resolved), 2.12, 2.11 (2s, $\left.\mathrm{Me}_{2}-4,6\right), 2.1$ (br, $\mathrm{NMe}_{2}$ ). ${ }^{13} \mathrm{C}$ NMR: $\left(25^{\circ} \mathrm{C}\right) \delta 166.6$ $\left(\mathrm{C}_{\text {ipso }}\right), 131.7,131.5,125.5,124.1,118.1(\mathrm{Ar}-\mathrm{C}), 64.7\left(\mathrm{CH}_{2} \mathrm{~N}\right)$, $46.3\left(\mathrm{NMe}_{2}\right), 20.7,18.9\left(\mathrm{Me}_{2}-4,6\right) ;\left(-70{ }^{\circ} \mathrm{C}\right) \delta 168$ and 167 $\left(\mathrm{C}_{\text {ipso, }}\right.$, ratio 5:1), 132-114 (Ar-C), $64.7\left(\mathrm{CH}_{2} \mathrm{~N}\right), 45.7$ (br s, $\left.\mathrm{NMe}_{2}\right), 21.3-19.0\left(\mathrm{Me}_{2}-4,6\right)$.

[Na $\left.\left\{\mathrm{OC}_{6} \mathrm{H}_{2}\left(\mathrm{CH}_{2} \mathrm{NMe}_{2}\right)_{2}-2,6, \mathrm{Me}-4\right\}\right]$ (2c). This phenolate complex is prepared via a procedure similar to the one described for 2a, and was obtained nearly quantitatively. Anal. Calcd for $\mathrm{C}_{13} \mathrm{H}_{21} \mathrm{NaN}_{2} \mathrm{O} .1 /{ }_{4} \mathrm{C}_{6} \mathrm{H}_{6}: \mathrm{C}, 66.01 ; \mathrm{H}, 8.60 ; \mathrm{N}, 10.62$. Found: C, 66.34; H, 8.83; N, 10.36. NMR data in benzene- $d_{6} .{ }^{1} \mathrm{H}$ NMR: $\delta 6.94$ (s, 2, Ar-H), 3.48 (br s, 4, $\mathrm{CH}_{2} \mathrm{~N}$ ), 2.29 (s, 3, p-Me), 1.95 (s, 12, $\left.\mathrm{NMe}_{2}\right)$. ${ }^{13} \mathrm{C}$ NMR: $\delta 166.9\left(\mathrm{C}_{i p s o}\right), 137.4$, 133.8, $118.0(\mathrm{Ar}-\mathrm{C}), 64.1\left(\mathrm{CH}_{2} \mathrm{~N}\right), 46.0\left(\mathrm{NMe}_{2}\right), 20.7$ (p-Me). Molecular weight determination by cryoscopy $(0.47 \mathrm{~g}$ in 28.13 and $57.64 \mathrm{~g}$ of benzene, $0.029-0.060 \mathrm{M}$ ): calcd for monomer, 244.3; found, 498 and 509 (degree of association: 2.05 and 2.10 respectively).

Structure Determination and Refinement. $\mathrm{Li}_{3} \mathrm{C}_{39} \mathrm{H}_{63} \mathrm{~N}_{6} \mathrm{O}_{3}$, $1 \mathrm{c}$. A plate-shaped, yellowish crystal was mounted on a glass capillary and transferred into the cold $\mathrm{N}_{2}$ stream of an Enraf-Nonius CAD4 diffractometer for data collection. Unit cell parameters were determined from a least squares treatment of the SET4 setting angles of 25 reflections in the range $9.30<\theta<16.10^{\circ}$ and were checked for the presence of higher lattice symmetry. ${ }^{28}$ All data were collected with a $\omega / 2 \theta$ scan mode. Data were corrected for $L p$ but not for absorption. The structure was solved using direct methods (SHELXS86) ${ }^{29}$ and subsequent difference Fourier syntheses and refined by full-matrix, least-squares techniques on $F$ (SHELX76). ${ }^{30}$ Some $\mathrm{H}$ atoms were introduced on calculated positions $(\mathrm{C}-\mathrm{H}=0.98 \AA$ ) and included in the refinement riding on their carrier atoms; others were located from a difference Fourier map and refined. All non-hydrogen atoms were refined with anisotropic thermal parameters; hydrogen atoms were refined with three common isotropic thermal parameters. Weights were introduced in the final refinement cycles. Three reflections were

(28) Spek, A. L. J. Appl. Crystallogr. 1988, 21, 578.

(29) Sheldrick G. M. SHELXS86. Program for crystal structure determination; University of Göttingen: Göttingen, Federal Republic of Germany, 1986.

(30) Sheldrick, G. M. SHELX76. Crystal structure analysis package: University of Cambridge: Cambridge, England, 1976.
Table VII. Crystal Data and Details of the Structure Determination of Complexes $1 \mathrm{c}$ and $2 \mathrm{c}$

\begin{tabular}{|c|c|c|}
\hline & $1 \mathrm{c}$ & $2 c$ \\
\hline $\begin{array}{l}\text { formula } \\
\text { mol wt } \\
\text { space group } \\
a, b, c(\AA)\end{array}$ & $\begin{array}{l}\mathrm{Li}_{3} \mathrm{C}_{39} \mathrm{H}_{63} \mathrm{~N}_{6} \mathrm{O}_{3} \\
684.79 \\
\left.P 2_{1} / n \text { (No. } 14\right) \\
42.381(5), 8.8417(11), \\
\quad 11.1802(10)\end{array}$ & $\begin{array}{l}\mathrm{Na}_{4} \mathrm{C}_{52} \mathrm{H}_{84} \mathrm{~N}_{8} \mathrm{O}_{4}\left(\mathrm{C}_{6} \mathrm{H}_{6}\right) \\
1055.36 \\
P 2 / c \text { (No. 13) } \\
16.021(2), 10.275(1) \\
24.190(2)\end{array}$ \\
\hline$\beta(\mathrm{deg})$ & $90.539(8)$ & $130.35(1)$ \\
\hline & $4189.2(8)$ & 303 \\
\hline$Z$ & 4 & 2 \\
\hline$D_{\mathrm{csic}}\left(\mathrm{g} \mathrm{cm}^{-3}\right)$ & 1.086 & 1.155 \\
\hline$\mu\left(\mathrm{cm}^{-1}\right)$ & 0.6 & 0.9 \\
\hline radiation & $\begin{array}{l}\text { MoK } \alpha(\mathrm{Zr} \text {-filtered }) \\
0.71073 \AA\end{array}$ & $\begin{array}{l}\text { MoK } \alpha \text { (graph-monochrom), } \\
0.71073 \AA\end{array}$ \\
\hline final $R, R_{\mathrm{w}},{ }^{a} S$ & $0.068,0.059,2.37$ & $0.0641,0.0683,1.53$ \\
\hline $\begin{array}{r}\min , \max \text { resd } \\
\text { dens }\left(e / \AA^{3}\right)\end{array}$ & $-0.31,0.3$ & $-0.32,0.32$ \\
\hline
\end{tabular}

left out of the refinement. Neutral atom scattering factors were taken from Cromer and $\mathrm{Mann}^{31}$ and corrected for anomalous dispersion. ${ }^{32}$ All calculations were carried out on a DEC 5000 system. Geometrical calculations and illustrations were done with PLATON. ${ }^{33}$

$\mathrm{Na}_{4} \mathrm{C}_{52} \mathrm{H}_{84} \mathrm{~N}_{8} \mathrm{O}_{4} \cdot \mathrm{C}_{6} \mathrm{H}_{6}, 2 \mathrm{c}$. A colorless, plate-shaped crystal was glued on top of a glass fiber and transferred immediately to the cold nitrogen stream of an Enraf-Nonius CAD4T diffractometer (rotating anode, $50 \mathrm{kV}, 200 \mathrm{~mA}$, graphite-monochromated Mo $\mathrm{K} \alpha$ radiation) for data collection. Unit cell parameters were determined from a least-squares treatment of the SET4 setting angles of 25 reflections with $11.5<\theta<13.9^{\circ}$. Unit cell parameters were checked for the presence of higher lattice symmetry. ${ }^{28}$ Data were corrected for $L p$ and for absorption (DIFABS; ${ }^{34}$ correction range $0.851-1.099$ ). The intensity control reflections showed no decay during the $14 \mathrm{~h}$ of X-ray exposure time. The structure was solved with direct methods (SHELX86) ${ }^{29}$ and subsequent difference Fourier analyses; the $\mathrm{C}(8), \mathrm{C}(9)$, and $C(10)$ atoms are disordered over two positions in a 56.6(7):43.4(7) ratio. Refinement on $F$ was carried out by full-matrix, leastsquares techniques. $\mathrm{H}$ atoms were introduced on calculated positions $(\mathrm{C}-\mathrm{H}=0.98 \AA)$ and included in the refinement riding on their carrier atoms. All non-H atoms were refined with anisotropic thermal parameters; $\mathrm{H}$ atoms, with one common isotropic thermal parameter ( $U=0.062(2) \AA^{2}$ ). Weights were introduced in the final refinement cycles, convergence was reached at $R=0.0641, R_{\mathrm{w}}=0.0683, w=1 /\left[\sigma^{2}(F)+0.000269 F^{2}\right]$. Crystal data and numerical details of the structure determination are given in Table VII. Final atomic coordinates and the equivalent thermal parameters are listed in Table V. Neutral atom scattering factors were taken from Cromer and $\mathrm{Mann}^{31}$ and corrected for anomalous dispersion. ${ }^{32}$ All calculations were performed with SHELX $76^{30}$ and PLATON ${ }^{33}$ (geometrical calculations and illustrations) on a DEC 5000 system.

Acknowledgment. This work was supported in part (P.A.v.d.S., W.J.J.S., and A.L.S.) by the Netherlands Foundation for Chemical Research (SON) with financial aid from the Netherlands Organisation for Advancement of Pure Research (NWO) and was also financially supported (M.P.H.) by the Innovation Oriented Research Program on Catalysis (IOP-Katalyse). X-ray data for 1c were kindly collected by A. J. M. Duisenberg, and J. M. Valk is kindly acknowledged for providing some of his sodium 2-[(dimethylamino)methyl]phenolate (2a).

Supplementary Material Available: Tables of anisotropic thermal parameters, all $\mathrm{H}$ atoms parameters, bond length and angles, and crystal data for $1 c$ and $2 c$, respectively (13 pages). Ordering information is given on any current masthead page.

(31) Cromer, D. T.; Mann, J. B. Acta Crystallogr. 1968, A24, 321.

(32) Cromer, D. T.; Liberman, D. J. Chem. Phys. 1970, 53, 1891

(33) Spek, A. L. Acta Crystallogr. 1990, A46, C34.

(34) Walker, N.; Stuart, D. Acta Crystallogr. 1983, A39, 158. 